\title{
Effects of business-as-usual anthropogenic emissions on air quality
}

\author{
A. Pozzer ${ }^{1,2}$, P. Zimmermann ${ }^{2}$, U.M. Doering ${ }^{3, *}$, J. van Aardenne ${ }^{3, * *}$, H. Tost ${ }^{4}$, F. Dentener ${ }^{3}$, G. Janssens-Maenhout ${ }^{3}$, \\ and J. Lelieveld ${ }^{2,5,6}$ \\ ${ }^{1}$ The Abdus Salam International center for Theoretical Physics, Earth System Physics, Trieste, Italy \\ ${ }^{2}$ Atmospheric Chemistry Department, Max Planck Institute for Chemistry, Mainz, Germany \\ ${ }^{3}$ European Commission, Joint Research Centre, Ispra, Italy \\ ${ }^{4}$ Institut für Physik der Atmosphäre, Johannes - Gutenberg Universität Mainz, Mainz, Germany \\ ${ }^{5}$ The Cyprus Institute, Energy, Environment and Water Research Center, Nicosia, Cyprus \\ ${ }^{6}$ King Saud University, Riyadh, Saudi Arabia \\ *now at: Öko-Institut e.V., Berlin, Germany \\ ** now at: Air and climate change-mitigation, European Environment Agency, Copenhagen, Denmark
}

Correspondence to: A. Pozzer (andrea.pozzer@mpic.de)

Received: 22 March 2012 - Published in Atmos. Chem. Phys. Discuss.: 5 April 2012

Revised: 5 July 2012 - Accepted: 11 July 2012 - Published: 1 August 2012

\begin{abstract}
The atmospheric chemistry general circulation model EMAC has been used to estimate the impact of anthropogenic emission changes on global and regional air quality in recent and future years $(2005,2010,2025$ and 2050). The emission scenario assumes that population and economic growth largely determine energy and food consumption and consequent pollution sources with the current technologies ("business as usual"). This scenario is chosen to show the effects of not implementing legislation to prevent additional climate change and growing air pollution, other than what is in place for the base year 2005, representing a pessimistic (but plausible) future.

By comparing with recent observations, it is shown that the model reproduces the main features of regional air pollution distributions though with some imprecisions inherent to the coarse horizontal resolution $(\sim 100 \mathrm{~km})$ and simplified bottom-up emission input.

To identify possible future hot spots of poor air quality, a multi pollutant index (MPI), suited for global model output, has been applied. It appears that East and South Asia and the Middle East represent such hotspots due to very high pollutant concentrations, while a general increase of MPIs is observed in all populated regions in the Northern Hemisphere. In East Asia a range of pollutant gases and fine particulate matter $\left(\mathrm{PM}_{2.5}\right)$ is projected to reach very high levels from 2005 onward, while in South Asia air pollution, including ozone, will grow rapidly towards the middle of the century.
\end{abstract}

Around the Persian Gulf, where natural $\mathrm{PM}_{2.5}$ concentrations are already high (desert dust), ozone levels are expected to increase strongly.

The population weighted MPI (PW-MPI), which combines demographic and pollutant concentration projections, shows that a rapidly increasing number of people worldwide will experience reduced air quality during the first half of the $21 \mathrm{st}$ century. Following this business as usual scenario, it is projected that air quality for the global average citizen in 2050 would be almost comparable to that for the average citizen in East Asia in the year 2005, which underscores the need to pursue emission reductions.

\section{Introduction}

Clean air is a prerequisite to human health and well-being. In spite of the introduction of less polluting technologies in industry, energy production and transport during the past decades, air pollution remains a major health risk (HTAP, 2010). Many epidemiological studies have demonstrated the negative impacts of air pollutants on human health, in particular in the urban environment (e.g. Pope et al., 2002; Mokdad et al., 2004). Air quality is a major issue in megacities worldwide (i.e. population centres with more than 10 million inhabitants), which are increasing in size and number. Megacities are strong localized pollution sources, though

Published by Copernicus Publications on behalf of the European Geosciences Union. 
their effects can extend over large distances of more than $1000 \mathrm{~km}$ downwind (Lawrence et al., 2007). In many OECD (Organisation for Economic Co-operation and Development) countries, air pollution is monitored routinely to test compliance with air quality legislation (UNECE, 1999; EPA, 2005; European Commission, 2008; Tørseth et al., 2012) and emission abatement strategies (Schöpp et al., 2010, and references therein). Despite abatement strategies in some regions, air pollution may be expected to increase globally with industrial activity, with serious implications on a range of scales. In this work, the global EMAC (ECHAM5/MESSy, Atmospheric Chemistry) model is used to analyse the influence of anthropogenic emissions on air quality worldwide. Following Fenger (1999) the analysis includes the five major air pollutants which can significantly impact human health, i.e. Particular Matter (particles with a diameter less than $\left.2.5 \mu \mathrm{m}, \mathrm{PM}_{2.5}\right)$, nitrogen dioxide $\left(\mathrm{NO}_{2}\right)$, sulphur dioxide $\left(\mathrm{SO}_{2}\right)$, ozone $\left(\mathrm{O}_{3}\right)$ and carbon monoxide $(\mathrm{CO})$. Our analysis of the influence of anthropogenic emissions is performed for selected time periods, i.e. preindustrial conditions, recent conditions (the year 2005) and projected future conditions (the years 2010, 2025 and 2050) using the recently developed Emission Database for Global Atmospheric Research, EDGAR-CIRCE (Climate change and Impact Research: the Mediterranean Environment, see Sect. 2, Anthropogenic emissions scenario).

Several emission scenarios are presented in the literature. The scenarios from the SRES (Special Reporton Emissions Scenarios, Nakicenovic et al., 2000) developed by the Intergovernmental Panel on Climate Change (IPCC) are widely used to assess the possible effects of future emissions on air quality on a global scale (e.g. Hogrefe et al., 2004; Jacobson and Streets, 2009). They included a range of optimistic and pessimistic scenarios for gases influencing climate change, but did not consider further air pollution emissions controls, except for $\mathrm{SO}_{2}$. Recently the Atmospheric Chemistry and Climate Model Intercomparison Project (ACCMIP, www.giss.nasa.gov/projects/accmip/) was initiated, which focuses on emission scenarios based on the Representative Concentration Pathways (RCP) (Lamarque et al., 2011; Meinshausen et al., 2011; van Vuuren et al., 2011a,b, and references therein). These scenarios, however, implicitly assume air pollution controls and are hence lacking a "worst case" scenario.

Previous studies of historical evolution and future projections of air quality (e.g. Szopa et al., 2006; Horowitz, 2006; Dentener et al., 2005, 2006; Stevenson et al., 2006) did consider optimistic, realistic and pessimistic cases. However, the resolution used in these studies was generally much lower than that used in this work and the simulations were performed only for the year 2030. The results presented here are expected to be more representative for densely populated regions. Finally, to our knowledge, no studies so far focused specifically on a combination of pollutants that influence hu- man health, but rather on single pollutants (e.g. Knowlton et al., 2004; Anenberg et al, 2010).

In this work only the effects of anthropogenic emissions are investigated, thus ignoring possible effects of climate change on the atmospheric composition. Only long term air quality levels are analyzed (annual averages), as the short term concentrations are strongly influenced by the local meteorology, transport and deposition processes which, in turn, are influenced by climatic changes, not included in this work. We present a Business as Usual (BaU) scenario (which represents a possible future with continuation of the past emission trends and without additional legislation to abate increasing air pollution and climate change) to illustrate the effects on the atmospheric composition that can be avoided by implementing additional emission control measures. Although a range of emission scenarios is available (see Sect. 2, Anthropogenic emissions scenario) we focus on the pessimistic $\mathrm{BaU}$ scenario, firstly because the other scenarios are more similar to the current situation and secondly because a $\mathrm{BaU}$ scenario may not be too far from reality (Garnaut et al., 2008). Finally, it is important for policy makers to understand the consequences of inaction.

This work has two objectives. The first is to compare the influence of anthropogenic emissions on air quality in different regions according to a multi-pollutant index, the second is to demonstrate the impact of no-further legislation in the deterioration of air quality worldwide. In Sect. 2 the model is presented and the scenario simulations are briefly described. In Sect. 3 the model results are analysed, firstly by comparing the results for the year 2005 with observational datasets and then by calculating the changes of pollutant concentrations between the different simulations (projected future). In Sect. 4 the multi-pollutant index is defined to evaluate air quality levels, and its time evolution is estimated on regional and global scales. Section 5 presents our conclusions.

\section{Model description and setup}

EMAC is a combination of ECHAM5 (Roeckner et al., 2006) (version 5.3.01) and the Modular Earth Submodel System (MESSy, version 1.9; Jöckel et al., 2005). An extensive evaluation of the model can be found in Jöckel et al. (2006) and Pozzer et al. (2007). In this study, the general circulation model (GCM) ECHAM5 has been used with a T106L31 resolution, corresponding to a horizontal resolution of $\approx 1.1 \times 1.1^{\circ}$ for the quadratic Gaussian grid, and with 31 vertical levels, up to $10 \mathrm{hPa}$ in the lower stratosphere. The model set-up used in this work was presented by Pozzer et al. (2012), so only differences and the central features are described here. Additionally in Pozzer et al. (2012) an evaluation of the model results was performed, showing that the model reproduces the main spatial and temporal atmospheric distributions of sulfate and ammonium aerosols while nitrate aerosol shows some discrepancies compared to observations. 
The latter is partly attributed to the loss of nitrate from filters at relatively high temperatures, so that the observations are not representative for summer conditions.

The atmospheric chemistry is simulated with the MECCA (Module Efficiently Calculating the Chemistry of the Atmosphere) submodel described by Sander et al. (2005), while the aerosol microphysics and gas-aerosol partitioning are calculated by the Global Modal-aerosol eXtension (GMXe) aerosol module (Pringle et al., 2010a,b). The emission and deposition routines are described in Kerkweg et al. (2006a,b), Pozzer et al. (2006) and Tost et al. (2007a,b).

To evaluate the effects of the emissions in the different air quality projections, the chemistry and the dynamics have been decoupled, hence there is no connection between changing greenhouse gas concentrations and the dynamics of the atmosphere, i.e. the GCM is used as a chemistrytransport model. More specifically, two sets of greenhouse gases (GHGs) are included in the EMAC model: one used by the radiation code which is estimated from a 2000-2009 average and is the same in all simulations performed, and one used in the chemistry calculations, described below. The Sea Surface Temperature (SST) and ice coverage were precalculated from a $10 \mathrm{yr}$ climatology (2000-2009) from the AMIPII data (Taylor et al., 2000; Hurrell et al., 2008). Accordingly, all simulations follow the same (i.e. binary identical) dynamics and meteorology, which can be considered as climatologically representative of the first decade of the 21 st century. Comparison of different simulations with identical dynamics and meteorology allows to diagnose differences caused by only emissions/chemistry. In all model runs, two years are simulated from which only the latter year output is analysed as the first one is considered as spin-up time.

In total, five simulation experiments were performed. In each simulation only the anthropogenic emissions were changed, while all other emissions and the model set-up were kept the same. The emissions refer to:

- natural conditions, where no anthropogenic emissions are included, termed the standard case natural (SC_natural).

- anthropogenic emissions for the year 2005, termed standard case 2005 (SC_2005).

- anthropogenic emissions for the year 2010, termed standard case 2010 (SC_2010).

- anthropogenic emissions for the year 2025, termed standard case 2025 (SC_2025).

- anthropogenic emissions for the year 2050, termed standard case 2050 (SC_2050).

More detailed information about the emissions is given in the section "Anthropogenic emission scenario".

To take into account the effects of the GHGs on atmospheric chemistry, mostly through changes to the hy- droxyl radical concentration by methane $\left(\mathrm{CH}_{4}\right)$ concentration changes, the GHGs have been scaled to the observed or projected values in each simulation. The projected GHGs concentrations have been adopted from the scenario A1B of the IPCC recommendation (see IPCC, 2001, appendix II), and it includes $\mathrm{CO}_{2}, \mathrm{CH}_{4}$ and $\mathrm{N}_{2} \mathrm{O}$, while CFCs and HFCs are from the WMO98 Scenario A1(baseline) following the Montreal Amendments. GHGs estimates for the SC_natural have been obtained for $\mathrm{CO}_{2}$ from Etheridge et al. (1998), for $\mathrm{N}_{2} \mathrm{O}$ from Machida et al. (1995), for $\mathrm{CH}_{4}$ from Etheridge et al. (2002) and for CFCs from Walker et al. (2000).

\section{Anthropogenic emission scenario}

The global anthropogenic emission inventory (EDGARCIRCE) used in this study has been prepared in the framework of the CIRCE Project (Climate Change and Impact Research: the Mediterranean Environment) by the EDGAR group (EDGAR, Emission Database for Global Atmospheric Research) of the EC-Joint Research Center Ispra (Italy), Air and Climate Unit (Doering et al., 2009a,b, 2010). The European project CIRCE focuses on the EU neighbouring countries with emphasis on the Mediterranean area, using a scenario developed with a European Commission perspective. This dataset includes emissions of the nitrogen oxides family $\left(\mathrm{NO}_{\mathrm{x}}\right)$, carbon monoxide $(\mathrm{CO})$, Non Methane Volatile Organic Compounds (NMVOCs), ammonia $\left(\mathrm{NH}_{3}\right)$, sulphur dioxide $\left(\mathrm{SO}_{2}\right)$, Black Carbon (BC) and Particulate Organic Matter (POM) from fossil fuel and biofuel combustion, industrial processes and the production and usage of solvents, agriculture and waste treatment.

The emission totals of all countries in the base year 2005 were projected up to 2050. Comparable to the study of Shindell et al. (2012) and in contrast to the RCP scenarios, the CIRCE projections differentiate the climate change (CC) measures from the air pollution control (AP) measures because the implementation of $\mathrm{CC}$ measures require a much larger and longer process of structural changes than the AP measures. Future emission scenarios were developed to identify the regions that will become most affected and might be most concerned about co-benefits from emission control measures. For this paper we used a reference scenario based on energy and fuel projections of the POLES model (Prospective Outlook for the Long term Energy System, Russ et al., 2007), and agriculture, land use and waste projections of the IMAGE model (Integrated Model to Assess the Global Environment) incorporating only the presently agreed policies affecting emissions.

With this $\mathrm{BaU}$ scenario that leaves out potential additional future emission control measures, we focus on the worst likely case. It explores the potential consequences of absence of further climate and air pollution policies beyond what was in place in the year 2005. Other scenarios were produced under the EDGAR-CIRCE project, namely the Global climate policy only (CC), the European air quality policy (BAP) and 
the Integrated air quality and climate policy (CAP), which explore different combinations of air quality and climate change reduction policies which may be applied in the future. The future emissions of pollutants and GHGs equivalents for the CC, BAP and CAP scenarios lead to a stabilisation or an improvement of the current air quality (Doering et al., 2010). For example, the projected $\mathrm{CO}$ and $\mathrm{BC}$ emissions in the $\mathrm{CC}$ scenario is $\sim 559$ and $\sim 5.4 \mathrm{Tg}$ (species) $\mathrm{yr}^{-1}$ respectively for the year 2050, which is $-4.7 \%$ and $-8.4 \%$ relative to the emissions estimated for the year 2005, while the BAP and CAP scenarios assume even larger decreases. As the scenarios present a large range of uncertainties without a clear indication of the most probable future situation, since it will strongly depend on political choices, we focus on the scenario where no further effective implementation of air pollution legislation or structural measures in energy production systems will be applied (i.e. BaU). This rather pessimistic scenario is chosen to show the impact of refraining from further measures against air pollution and climate.

Beyond 2005, no change in technologies for combustion (power industry, transport), industrial processes (steel, cement, chemicals), waste treatment and agriculture are assumed. Either the activity data or implied emission factors are scaled up. Nevertheless, improvement in the energy efficiency of the technologies already in place in the year 2005 are expected for the projected years. The solvent-related activity is driven only by population, while the energy-related activities are driven by population and economic growth, following the oil, gas and coal markets modeled in POLES for the different world regions. The BaU scenario of POLES assumes a continuation of the trend from 1990-2005: the energy consumption per GDP will decline further but will be more than offset by economic growth and is projected to be $79 \%$ above its 2005 levels by 2050 . The fossil fuels dominate for $75 \%$ the fuel mix until 2030 and then they are expected to decrease with $10 \%$ assuming that renewable and nuclear power will grow. The assumptions are well in line with those incorporated in world energy models from the International Energy Agency (IEA) World Energy Outlook 2006 as shown by Schade and Wiesenthal (2007). The agriculturerelated activities are mainly driven by population and corresponding food demand, and following the global agricultural trade with regional food prices and with livestock-cropland use interactions as calculated by IMAGE. As described by van Vuuren et al. (2009), the IMAGE baseline scenario projects the global agricultural production to grow by more than $50 \%$ through increased productivity and an extension of the agricultural area with about $10 \%$. Both models, POLES and IMAGE, use the medium-fertility population projection variant of the 2004 revision of world population prospects of United Nations Department of Economic and Social Affairs/Population Division (UNDP) (2005), expecting 9 billion people by $2050, \sim 45 \%$ more than in 2005 .
Table 1. Global tracer gases and aerosol emissions used in this work in $\mathrm{Tg} \mathrm{yr}^{-1}$.

\begin{tabular}{lcccc}
\hline \multirow{2}{*}{ species } & \multicolumn{4}{c}{ anthropogenic } \\
\cline { 2 - 5 } & 2005 & 2010 & 2025 & 2050 \\
\hline $\mathrm{NO}_{\mathrm{x}}$ & 92.3 & 99.1 & 126.2 & 167.2 \\
$\mathrm{SO}_{2}$ & 132.0 & 157.0 & 192.2 & 263.9 \\
$\mathrm{CO}$ & 587.0 & 615.8 & 746.8 & 849.7 \\
$\mathrm{BC}$ & 6.0 & 6.0 & 6.9 & 7.6 \\
$\mathrm{POM}$ & 18.6 & 18.8 & 21.7 & 26.6 \\
\hline
\end{tabular}

The total amounts of trace gases and aerosol emissions are listed in Table 1 for the most significant species, while the sectoral breakdown is shown in the Supplement.

The EDGAR-CIRCE emission dataset is gridded on a $0.1 \times 0.1$ degree latitude $\times$ longitude grid using point source locations for power industry, fuel production and process industry, line sources for the transport sectors and diffusive distributions using the Food and Agriculture Organization Geonetwork (www.fao.org/geonetwork) global land cover map and the Center for International Earth Science Information Network (CIESIN), rural and urban population as proxy data. A monthly distribution for agricultural sources based on LOTOS (Long Term Ozone Simulation; Builtjes, 1992; Veldt, 1992) and GENEMIS (Generation and Evaluation of Emission Data; Friedrich and Reis, 2004) is imposed. The emissions are distributed vertically in the model as described in Pozzer et al. (2009).

Natural/biogenic emissions have been calculated as in Pozzer et al. (2012) while volcanic emissions (particularly important for $\mathrm{SO}_{2}$ ) are based on the AEROCOM dataset (Dentener et al., 2006). The natural/biogenic emissions are the same in all simulations.

The biomass burning contribution was added estimating the climatological emissions of the years 1997-2009 from the Global Fire Emissions Database (GFED version 3, van der Werf et al., 2010). The data has a $0.5 \times 0.5^{\circ}$ spatial resolution and a monthly temporal resolution. The same biomass burning emissions are used in all simulations performed.

\section{Results}

Though the EMAC model accounts for high time resolution variability (10 min time step) and applies monthly emissions, we largely focus on annual averages in the analysis of the results. The model has been used in a free running mode, i.e. without nudging to actual meteorological conditions. This prohibits comparing the results to instantaneous observations. The model is expected to represent the atmospheric dynamics on a climatological, i.e. decadal, time scale 
while single episodes do not temporally coincide with those in reality. Furthermore, many observational datasets are readily available as annual averages, without detailed information about sampling frequencies (Sect. 3.1). Finally, we focus on surface values of the pollutant species because it enables comparison with station observations which are generally in locations where pollutant concentrations are considered to be most relevant for human health.

\subsection{Year 2005 evaluation}

The EMAC model has been extensively evaluated previously in different publications, both for gas phase trace gases (e.g. Jöckel et al., 2006; Pozzer et al., 2007), aerosol compounds (e.g. Pringle et al., 2010a; Pozzer et al., 2012; De Meij et al., 2005) and for deposition (Tost et al., 2007a). In these efforts large numbers of observations have been used to test the model performance, e.g. in reproducing $\mathrm{O}_{3}, \mathrm{NO}_{\mathrm{x}}, \mathrm{CO}$, Volatile Organic Compounds (VOC) and semi-volatile inorganic aerosol species and gases such as $\mathrm{HNO}_{3}$ and $\mathrm{NH}_{3}$. Nevertheless, additional comparison of model output to observations at the surface is useful, e.g. for $\mathrm{SO}_{2}, \mathrm{O}_{3}$ and $\mathrm{NO}_{2}$, which play an important role in air quality.

Three different datasets were used to analyse the model results:

- EPA (the United States Environmental Protection Agency) network: ambient concentrations of pollutants in outdoor air are measured at more than 4000 monitoring stations operated mainly by state environmental agencies. The EPA provides an annual summary for each monitoring station (Edgerton et al., 1990), of which the data can be obtained from the AirData web site (http://www.epa.gov/airdata).

- EEA (The European Environment Agency): this agency of the European Union offers a range of information on the regional environment. The public air quality database system of the EEA is the AirBase (http://www. eea.europa.eu/themes/air/airbase). It contains air quality monitoring information from more than 30 participating countries throughout Europe. AirBase is managed by the European Topic Centre on Air pollution and Climate change Mitigation (ETC/ACM) on behalf of the EEA. In this work only annual statistics have been used (also available in the Airbase database).

- EANET (The Acid Deposition Monitoring Network in East Asia) network: this initiative supports regional cooperation among the participating countries (i.e. China, Indonesia, Japan, Malaysia, Mongolia, Philippines, Republic of Korea, Russia, Thailand, Viet Nam, Cambodia, Lao People's Democratic Republic and Myanmar). Regular monitoring started in January 2001. In this work, data from 28 stations of the EANET network were used. The data were downloaded from http://www.eanet.cc/product/index.html (Asia Center for Air Pollution Research (ACAP), 2011).

Simulation SC_2005 was used for comparison with the observations as the emissions for the year 2010 are projection based. Thus we compared the model results with observations from the EEA, EPA and EANET dataset for the year 2005. It must be stressed that the EEA and EPA databases were preferred to other databases because they cover all the pollutants of interest. Additionally, the large numbers of stations allow a sound statistical comparison with the model using annually averaged values. It must be stressed that, although the sampling is considered to be uniform (i.e. 1-h frequency for EPA and EEA network), this is not always the case and some discrepancies could also be related to non uniform sampling.

As shown in Table 2, and Fig. 1, the model reproduces the observed distribution well for $\mathrm{O}_{3}$ and $\mathrm{PM}_{2.5}$. Model average ozone compares well with the EPA observations, and almost all modelled values lie well within a factor of two of the observations. In general more than $\sim 80 \%$ of the modelled values are within a factor of two, considering all datasets.

The dry $\mathrm{PM}_{2.5}$ mass simulated by the model agrees well with the observations. Although the simulated values are generally low biased by $30-40 \%$ compared to the EPA and EEA dataset, they are mostly within a factor of 2 of the observations ( $\sim 68 \%$ and $\sim 81 \%$ of the values, respectively). As shown by Tsyro (2005, and references therein), this underestimation is a known issue present in many air quality models. The water content of the aerosol at $50 \%$ relative humidity (required when using the gravimetric measurement method) could explain the model underestimation, accounting for 20 $35 \%$ of the total aerosol mass, depending on the composition. Additionally, the coarse resolution of the model, which cannot reproduce local effects on fine aerosols, could also contribute to the underestimation. Nevertheless we obtain (see Fig. 1) very similar patterns (although low in absolute terms) compared to those derived by van Donkelaar et al. (2010), who estimated the $\mathrm{PM}_{2.5}$ mass at $50 \%$ relative humidity from satellite observations.

In the case of $\mathrm{SO}_{2}$, the modelled mixing ratios are associated with larger discrepancies. For the EPA network, the model reproduces the observed values within a factor of two in more than $71 \%$ of the locations, though with some small underestimations. For Europe and East Asia, the observations are more scattered, i.e. with larger variance (not shown). In Europe the model tends to overestimate the mean observed values (Fig. 1) by almost a factor of two. The $\mathrm{SO}_{2}$ emissions of the EDGAR-CIRCE dataset might overestimate the sulfur content of the European coal and are also higher than the officially reported EMEP (European Monitoring and Evaluation Programme, Vestreng et al., 2007, 2009) emissions (Pozzer et al., 2012). In Asia, the modelled averages agree well with the observations, though this is merely due to balancing of extremes: in fact, only $\sim 32 \%$ of the modelled values lies 

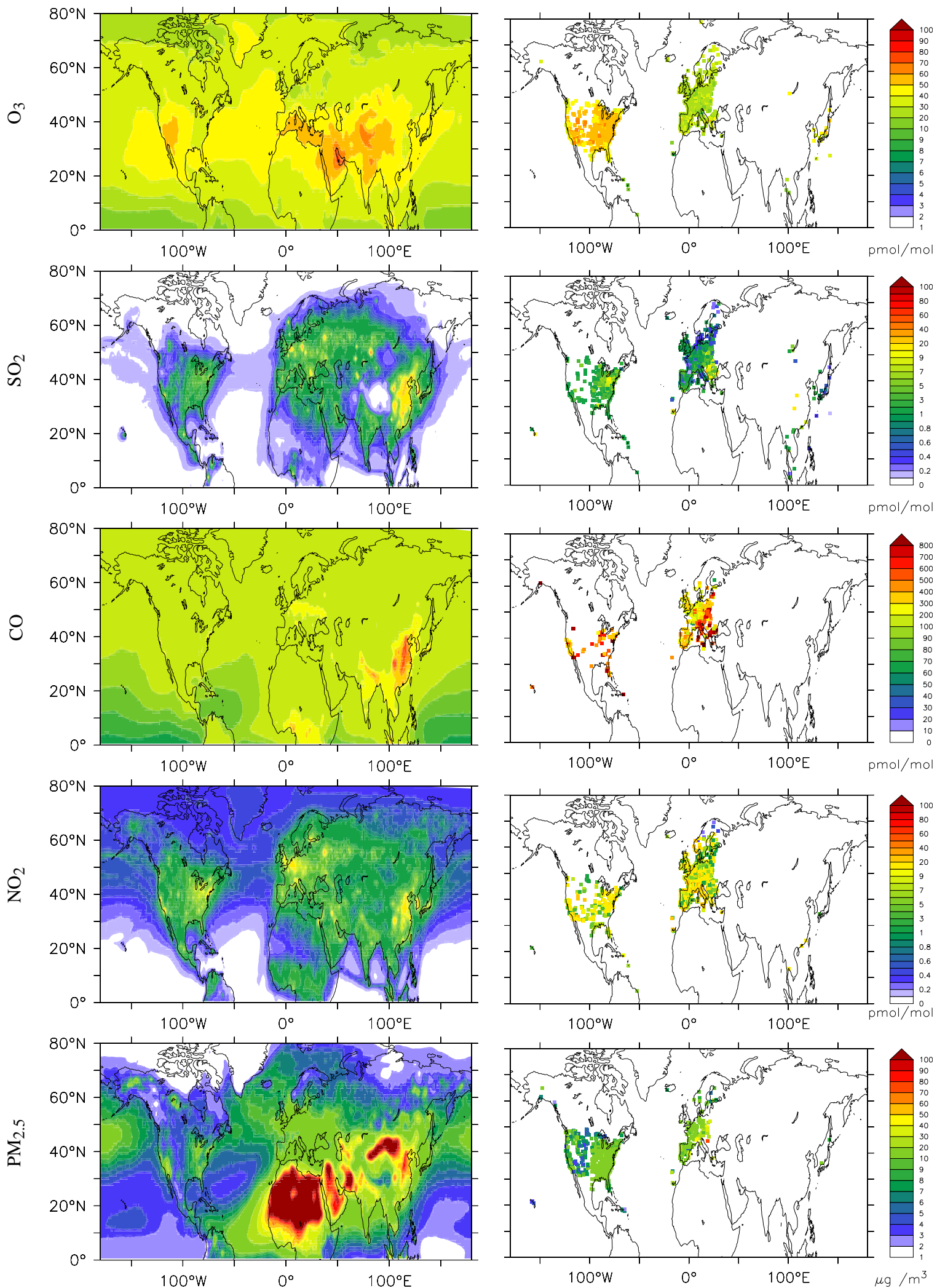

Fig. 1. LEFT PANELS: simulated annual mean mixing ratios (in pmol $\mathrm{mnol}^{-1}$ and $\mu \mathrm{g} \mathrm{m}^{-3}$ for $\mathrm{PM}_{2.5}$ ) for the year 2005. RIGHT PANELS: annual mean (in pmol mnol ${ }^{-1}$ and $\mu \mathrm{g} \mathrm{m}^{-3}$ for $\mathrm{PM}_{2.5}$ ) from the EPA, EEA and EANET network observations for the year 2005. The trace gases (from top to bottom) are $\mathrm{O}_{3}, \mathrm{SO}_{2}, \mathrm{CO}, \mathrm{NO}_{2}$ and $\mathrm{PM}_{2.5}$. 
Table 2. Summary of the comparison of model data with observations. N.stat. is the number of locations/stations used in the comparison. $\mathrm{OAM}$ and MAM are the arithmetic mean of the observations and of the model, respectively. $\mathrm{O}_{3}, \mathrm{SO}_{2}, \mathrm{NO}_{2}, \mathrm{CO}_{\text {and }} \mathrm{O}_{\mathrm{x}}$ are in nmol mol ${ }^{-1}$, while $\mathrm{PM}_{2.5}$ is in $\mu \mathrm{g} \mathrm{m}^{-3}$. The model has been sampled at the locations of the observations, and the calculations are based on annual averages. PF2 is the percentage of model results within a factor of two of the observations and PF0.2 is the percentage of model results within $20 \%$ of the observations. $\mathrm{O}_{\mathrm{x}}$ represents $\mathrm{NO}_{2}+\mathrm{O}_{3}$.

\begin{tabular}{lccccccc}
\hline & & \multicolumn{7}{c}{ All stations } \\
\cline { 3 - 8 } species & network & N.stat. & MAM & OAM & MAM/OAM & PF2 & PF0.2 \\
\hline $\mathrm{O}_{3}$ & EPA & 1253 & 41.6 & 52.6 & 0.8 & 99.9 & 44.4 \\
$\mathrm{O}_{3}$ & EEA & 2039 & 36.1 & 24.9 & 1.4 & 86.3 & 21.4 \\
$\mathrm{O}_{3}$ & EANET & 17 & 41.4 & 36.4 & 1.1 & 82.3 & 58.8 \\
$\mathrm{SO}_{2}$ & EPA & 527 & 2.7 & 3.8 & 0.7 & 71.9 & 24.1 \\
$\mathrm{SO}_{2}$ & EEA & 2285 & 4.3 & 2.5 & 1.7 & 40.1 & 11.9 \\
$\mathrm{SO}_{2}$ & EANET & 35 & 3.4 & 3.1 & 1.1 & 31.4 & 17.2 \\
$\mathrm{NO}_{2}$ & EPA & 407 & 6.5 & 11.9 & 0.5 & 53.8 & 17.2 \\
$\mathrm{NO}_{2}$ & EEA & 2793 & 6.7 & 15.0 & 0.4 & 43.8 & 11.0 \\
$\mathrm{NO}_{2}$ & EANET & 5 & 5.4 & 15.4 & 0.3 & 20.0 & 20.0 \\
$\mathrm{CO}$ & EPA & 452 & 170.5 & 545.0 & 0.3 & 25.7 & 0.2 \\
$\mathrm{CO}$ & EEA & 1280 & 184.6 & 563.4 & 0.3 & 36.8 & 8.4 \\
$\mathrm{Ox}$ & EPA & 364 & 49.2 & 62.4 & 0.8 & 100.0 & 56.4 \\
$\mathrm{Ox}$ & EEA & 1930 & 42.5 & 37.5 & 1.1 & 99.3 & 68.1 \\
$\mathrm{PM}_{2.5}$ & EPA & 1245 & 8.7 & 12.3 & 0.7 & 68.1 & 17.4 \\
$\mathrm{PM}_{2.5}$ & EEA & 275 & 11.1 & 17.9 & 0.6 & 81.1 & 34.3 \\
$\mathrm{PM}_{2.5}$ & EANET & 2 & 8.3 & 11.6 & 0.7 & 100.0 & 50.0 \\
\hline
\end{tabular}

within a factor of two to the observations. As shown by Zhao et al. (2012), the EDGAR-CIRCE emissions present generally higher $\mathrm{SO}_{2}$ emissions compared to other datasets, with strong differences on regional or smaller scales. Finally, the low number of observations for the EANET network could influence the robustness of the results, which could be statistically weak as based only on 35 points/stations.

Despite the reasonable agreement between model results and observations for $\mathrm{O}_{3}, \mathrm{PM}_{2.5}$ and $\mathrm{SO}_{2}$, for $\mathrm{CO}$ and $\mathrm{NO}_{2}$ significant discrepancies with the observational datasets are apparent. The model tends to underestimate the observed values by up to a factor of two to three for $\mathrm{NO}_{2}$ and $\mathrm{CO}$. These results for $\mathrm{CO}$ with the EMAC model seems to be in contrast with previous findings (Jöckel et al., 2006; Pozzer et al., 2007), which showed much better agreement with the observations.

To further investigate these discrepancies, an additional observational dataset has been used: the $\mathrm{CO}$ observations from the NOAA ESRL GMD (National Oceanic and Atmospheric Administration, Earth System Research Laboratory, Global Monitoring Division, Boulder, CO, USA) cooperative air sampling network (Novelli et al., 1998). The same dataset was used in the work of Jöckel et al. (2006) and Pozzer et al. (2007), and these observations were collected for non-polluted conditions avoiding local contamination (Haas-Laursen and Hartley, 1997). Compared to these observational data, the simulated annual $\mathrm{CO}$ differs by maximum $40 \%$; and for $\sim 90 \%$ of the locations the differences are within $30 \%$ (not shown). Finally, considering only locations of the NOAA ESRL GMD dataset outside Antarctica, all modelled calculated annual means are within $20 \%$ of the observations. These results are very similar to those obtained by Pozzer et al. (2007). Therefore, if the same observational dataset is used (NOAA ESRL GMD), the agreement between model results and observations is comparable to that obtained by Pozzer et al. (2007). This agreement is much better than that suggested by the comparison of model results with the EPA and EEA observations. Apparently, the total CO source in the model is quite realistic and the concentration of $\mathrm{OH}$, the main sink of $\mathrm{CO}$, is also well reproduced globally, as described in Sect. 3.2.5, and it is very similar to what was obtained by Jöckel et al. (2006).

To further investigate if the global CO distribution is well reproduced, an additional comparison for $\mathrm{CO}$ near the surface was performed using satellite data. Satellite observations of $\mathrm{CO}$ are provided by the MOPITT (Measurements Of the Pollution In The Troposphere) instrument (Drummond and Mand, 1996), which flies on the Terra platform. The MOPITT dataset has been extensively evaluated and used in many studies (e.g. Emmons et al., 2004, 2009; Pfister et al., 2005; Liu et al., 2011). Here we used the level 3 (with monthly temporal resolution) version 4 (V92.0.1) of 


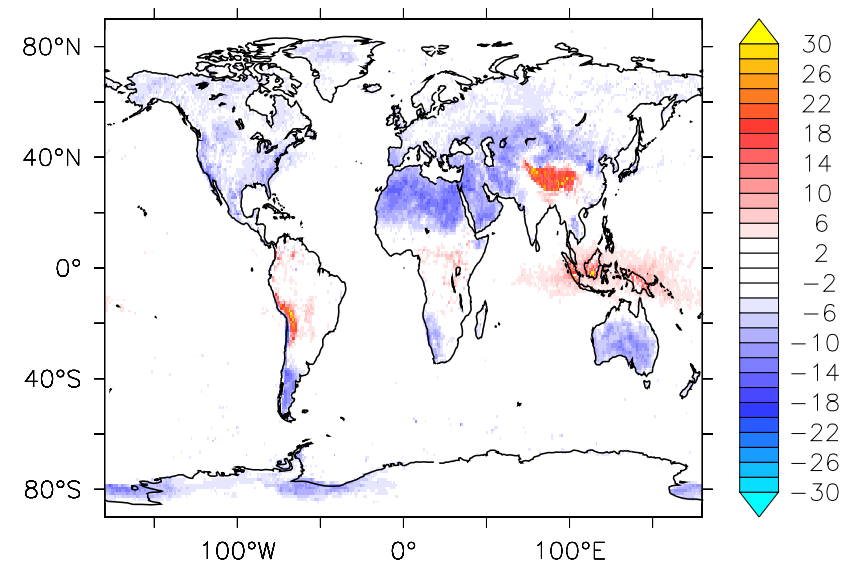

Fig. 2. Annual mean carbon monoxide relative difference (in \%) between model results and MOPITT satellite observations near the surface. The model CO was calculated on the MOPITT kernel.

the MOPITT product, with a spatial resolution of $1 \times 1^{\circ}$. Analogously to the stations observations, also here only the year 2005 of the MOPITT data has been used for the comparison. It should be mentioned that the MOPITT product is not only derived from direct observations but also contains modelled information (see Deeter et al., 2003, 2004, for information regarding the MOPITT CO retrieval algorithm). Nevertheless, its use can provide additional insight into the EMAC representation of $\mathrm{CO}$, having a similar spatial resolution. In Fig. 2, the annual mean modelled and remotely sensed near-surface CO are compared. The appropriate averaging kernels of the satellite retrival algorithm have been applied to the model output to enable a meaningful comparison. Generally the model results are within $30 \%$ of the satellite observations. Some small overestimations are present in the tropics and over highly elevated topography, due to a model overestimation of $\mathrm{CO}$ mixing ratios in the free troposphere. Relatively small model underestimations occur in the extratropics. In particular over the USA the model underestimates the satellite observed CO by $15 \%$, well below that suggested by the comparison of the model results with the EPA data. Such small differences also occur over Europe (generally below $\sim 10 \%$ ), East Asia (below $\sim 6 \%$ ), while larger differences occur over the Sahara and the Middle East $(\sim 15 \%)$. Hence the model tends to underestimate the CO concentrations, although much less (below $\sim 15 \%$ ) than suggested by the comparison with the EPA and EEA observations. This general underestimation is consistent with our total CO emissions $\left(\sim 1052 \mathrm{Tg} \mathrm{yr}^{-1}\right)$, which is $\sim 20 \%$ lower than that suggested by Hooghiemstra et al. (2011), based on inverse modeling. These findings confirm the work of Shindell et al. (2006), who showed that the underestimation of the modelled CO with respect to the MOPITT observations is present in many atmospheric chemistry models and suggests that year-round emissions "are greatly underestimated in current inventories".
Overall the CO source strength is reasonably represented: when compared to MOPITT, which has a similar resolution as the simulations used in this work, the EMAC model is able to reproduce the observations consistently or with a minor underestimation. Hence this analysis suggests that the CO observations in the EPA, EEA and EANET networks are strongly influenced by local pollution, which is difficult to accurately simulate by the EMAC model at T106 resolution. The observational networks used here often include stations in locations with heavy traffic or industry. For example $\sim 25 \%\left(160 \mathrm{Tg} \mathrm{yr}^{-2}\right)$ of the total CO emissions are due to fossil fuel combustion by traffic. Similar findings were obtained by Qian et al. (2010), who, thanks to model results on different resolution, quantified the sub-grid variability (SGV) of trace gases and aerosols, showing that "Mostly inert and long-lived trace gases and aerosols, such as $\mathrm{CO}$ and $\mathrm{BC}$, are more likely to have broad and skewed distributions (i.e. larger SGV) over polluted regions", while "secondary trace gases and aerosols, such as $\mathrm{O}_{3}$, sulfate, ammonium, and nitrate, are more likely to have a relatively uniform probability distribution (i.e. smaller SGV)". This implies that $\mathrm{O}_{3}$ generally has a smaller SGV than CO, and that the comparison of model results with the observations is rather robust. In the case of $\mathrm{PM}_{2.5}$, this is a combination of bulk and secondary aerosol and hence it is difficult to estimate the real influence of SVG on the comparison. Associated with the SVG of different pollutants and the inability of the model to reproduce local sources (but rather an average over large areas), the model results should be considered a lower limit of the real concentrations.

$\mathrm{NO}_{2}$ is also generally underestimated by the model (note however the low number of stations in the EANET network) while there are no indications that the emissions are equally incorrect. We attribute the discrepancy to underrated direct emissions of $\mathrm{NO}_{2}$ (all $\mathrm{NO}_{\mathrm{x}}$ is emitted as $\mathrm{NO}$ ) and possibly a too slow conversion of $\mathrm{NO}$ into $\mathrm{NO}_{2}$ by peroxy radicals or other oxidants in polluted air. Furthemore, a recent study by Miyazaki et al. (2012), based on a model inversion of satellite data, suggests that anthropogenic $\mathrm{NO}_{\mathrm{x}}$ emissions are generally underestimated in inventories. The model probably underestimates the photochemistry of reactive hydrocarbons near pollutant sources, e.g. because it does not account for aromatics. Nevertheless, what is most relevant for air quality is the concentration of total oxidant $\left(\mathrm{NO}_{2}+\mathrm{O}_{3}\right)$, which is well represented. In Table 2, the comparison with the total oxidant $\mathrm{O}_{\mathrm{x}}\left(\mathrm{NO}_{2}+\mathrm{O}_{3}\right)$ is shown, though only for the EPA and EEA networks, because EANET does not include a sufficient number of stations to derive meaningful statistics. The model results show reasonable agreement with both the EPA and EANET measurements, as more than $99 \%$ and $56 \%$ of the modelled values are within a factor of two and 0.2 , respectively, of the observations, implying that the total oxidant is well represented in the model. 

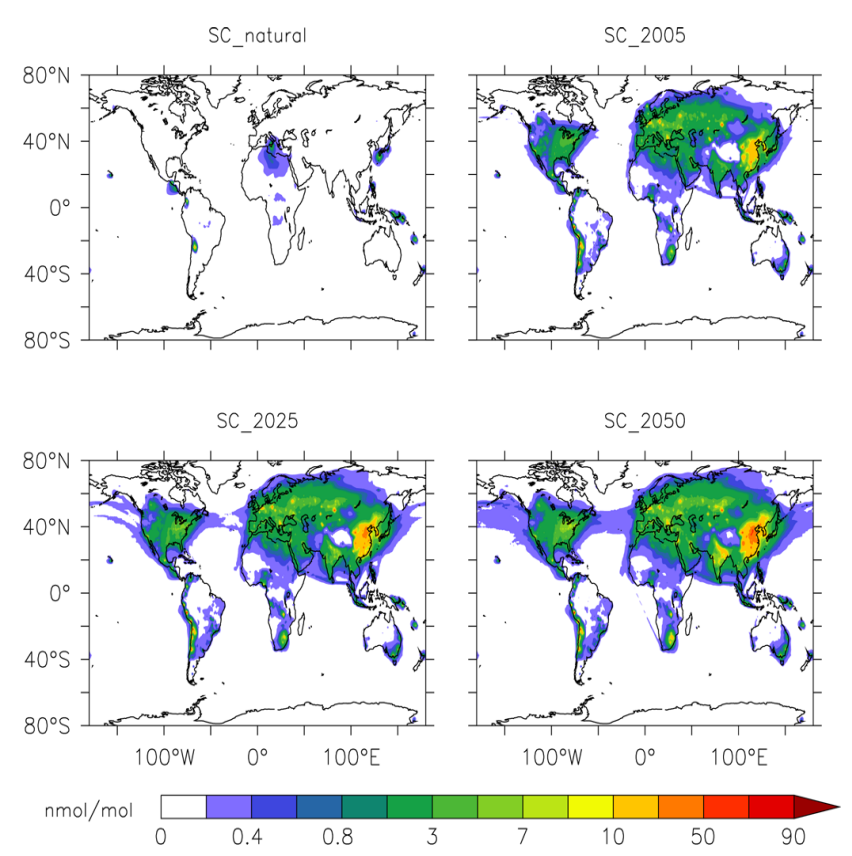

Fig. 3. Model calculated annual mean near-surface sulphur dioxide in nmol mol ${ }^{-1}$ from simulation SC_natural, SC_2005, SC_2025 and SC_2050.

\subsection{Future projections}

\subsection{1 $\mathrm{SO}_{2}$}

In Fig. 3 the annual mean of near-surface sulphur dioxide is shown for the different simulations. As expected, the $\mathrm{SO}_{2}$ mixing ratios in background locations from simulation $S C \_n a t u r a l$ are below $1 \mathrm{nmol} \mathrm{mol}^{-1}$, since $\mathrm{SO}_{2}$ is only emitted by relatively small natural sources (e.g. volcanoes are typically on land and release $29 \mathrm{Tg} \mathrm{yr}^{-1}$ ) and $\mathrm{SO}_{2}$ in the marine atmosphere is formed by the oxidation of dimethyl sulphide (DMS). The annual mean near-surface mixing ratios from other simulations are remarkably different, as the anthropogenic emissions increase dramatically in simulations SC_2005, SC_2010, SC_2025 and SC_2050. As shown in Fig. 3, including the anthropogenic emissions drastically increases the near-surface mixing ratios with time. This is also illustrated by Table 3 in which the atmospheric burdens of selected tracers are listed. While $\mathrm{SO}_{2}$ sources in simulation $S C \_$natural lead to a burden of $0.3 \mathrm{Tg}$, in simulation $S C \_2005$ the burden strongly increases by a factor of $3(0.9 \mathrm{Tg})$. The projected increase for the year 2050 (from simulation SC_2050) is around $1.8 \mathrm{Tg}$, which is six times the burden in the atmosphere estimated in the simulation $S C \_n a t u r a l$. A doubling of the burden of $\mathrm{SO}_{2}$ is projected between the years 2005 and 2050, consistent with the increase of the anthropogenic emissions. It is clear from Fig. 3 that China is the major emitter of $\mathrm{SO}_{2}$ already during the simulated year 2005, and it is expected to remain so up to 2050, also shown in previous studies (Pozzer et al., 2012; Lu et al.,
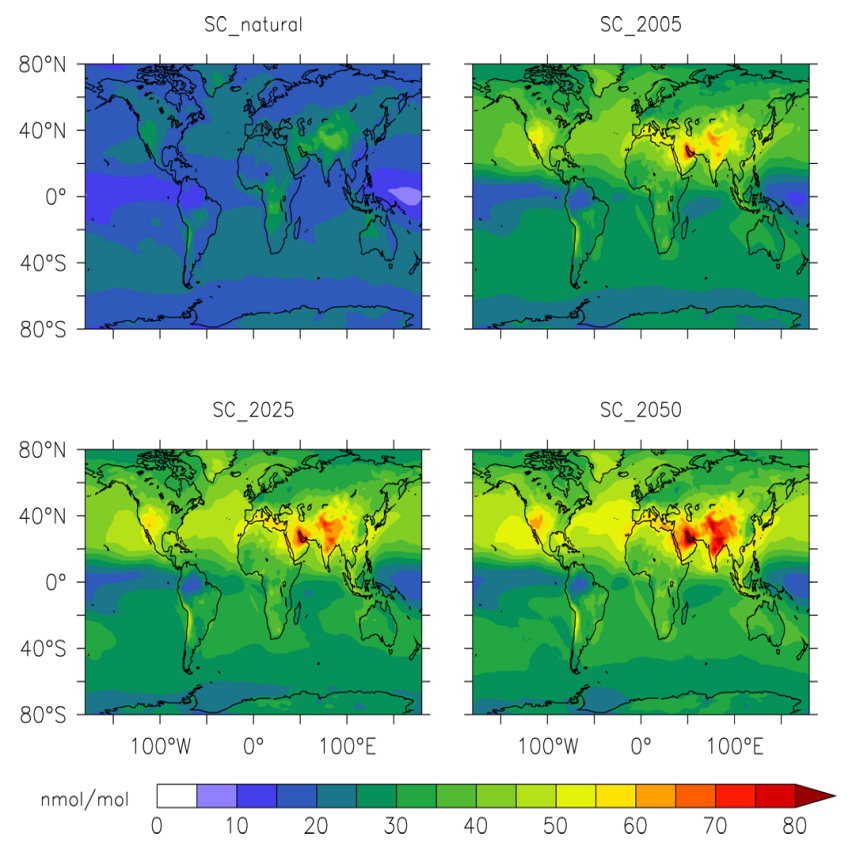

Fig. 4. Model calculated annual mean near-surface ozone in nmol mol ${ }^{-1}$ from simulation SC_natural, SC_2005, SC_2025 and SC_2050.

2010, 2011). In 2050 the densely populated northern part of India will also be exposed to very high $\mathrm{SO}_{2}$ mixing ratios. Interestingly, the model results suggest that toward $2050 \mathrm{In}$ dia may have $\mathrm{SO}_{2}$ mixing ratios comparable to those in eastern China in 2005, while in simulation SC_2025, apart from some local hot spots, the large scale $\mathrm{SO}_{2}$ mixing ratios are still an order of magnitude lower than in eastern China. Analogously, increasing emissions in some countries in eastern Europe and southern Russia are projected to lead to high levels of $\mathrm{SO}_{2}$, and comparably also some locations in central Asia. The $\mathrm{SO}_{2}$ is not uniformly distributed on large scales, due to its short lifetime (few days). Hence, local mixing ratios can vary tremendously. Generally, $\mathrm{SO}_{2}$ reaches high levels in urban locations in Europe, eastern USA, South America and South Africa in all simulations with anthropogenic emissions included.

It must be stressed that the increase of the burden does not directly translate into a direct increase of the maximum of $\mathrm{SO}_{2}$ levels. The model calculates local annual mean maxima in hot spot locations of about $24,86,91,89$, and $88 \mathrm{nmol} \mathrm{mol}^{-1}$ for SC_natural, SC_2005, SC_2010, SC_2025 and $S C 2050$, respectively. The large increases of $\mathrm{SO}_{2}$ mixing ratios are associated with the rapidly growing emissions in countries with emerging economies (e.g. India, China), while sources in other nations that strongly emitted in 2005 tend to not contribute to future increases of the total $\mathrm{SO}_{2}$ burden (but rather decrease). 
Table 3. Global burdens of $\mathrm{CO}, \mathrm{SO}_{2}, \mathrm{NO}_{2}$ and $\mathrm{O}_{3}$ in $\mathrm{Tg}$. The standard deviations due to the seasonal cycle are listed within parentheses. $\mathrm{O}_{3}$ represents the tropospheric ozone, only integrated from the surface to the tropopause.

\begin{tabular}{l|cc|cc|cc|cc|cc|c}
\hline species & \multicolumn{2}{|c|}{ SC_natural } & \multicolumn{2}{c|}{$S C \_2005$} & SC_2010 & \multicolumn{2}{c}{$S C \_2025$} & \multicolumn{2}{|c}{$S C \_2050$} \\
\hline $\mathrm{CO}$ & 200.6 & $(22.8)$ & 393.3 & $(18.9)$ & 400.4 & $(19.7)$ & 446.4 & $(21.4)$ & 484.7 & $(22.9)$ \\
$\mathrm{SO}_{2}$ & 0.3 & $(0.0)$ & 0.9 & $(0.2)$ & 1.0 & $(0.3)$ & 1.3 & $(0.4)$ & 1.8 & $(0.6)$ \\
$\mathrm{NO}_{2}$ & 1.9 & $(0.1)$ & 2.1 & $(0.1)$ & 2.3 & $(0.1)$ & 2.3 & $(0.1)$ & 2.4 & $(0.1)$ \\
$\mathrm{O}_{3}$ & 273.4 & $(12.6)$ & 387.7 & $(18.3)$ & 390.5 & $(18.2)$ & 416.2 & $(19.6)$ & 442.4 & $(20.8)$ \\
\hline
\end{tabular}

\subsection{2 $\mathrm{O}_{3}$}

Different from $\mathrm{SO}_{2}, \mathrm{O}_{3}$ is more homogeneously distributed in accordance with its atmospheric lifetime of several weeks (see Fig. 4), with global annual mean hot spot maxima of 41, 78, 77, 84 and $95 \mathrm{nmol} \mathrm{mol}^{-1}$ for simulations SC_natural, SC_2005, SC_2010, SC_2025 and SC_2050, respectively. Similar to $\mathrm{SO}_{2}$, northern India is progressively becoming strongly affected by high $\mathrm{O}_{3}$ mixing ratios, with a continual increase up to 2050. The already high $\mathrm{O}_{3}$ mixing ratios over the Persian Gulf in simulation SC_2005 are projected to drastically increase further in future, with annual average mixing ratios higher than $90 \mathrm{nmol} \mathrm{mol}^{-1}$ in the year 2050 with an increase of the annual average equal to $70 \mathrm{nmol} \mathrm{mol}^{-1}$ with respect to simulation $S C \_n a t u r a l$. The high levels of ozone in this region are caused from a generally high background by atmospheric transport, strong insolation, a shallow boundary layer over the Gulf and large local precursor emissions (Lelieveld et al., 2009; Smoydzin et al., 2012). Unless the anticipated emission trend is reversed, the Persian Gulf is destined to become a hot spot of poor air quality due to the high ozone levels.

Interestingly, China is not expected to be subjected to very high levels of ozone, but instead mean mixing ratios appear rather constant up to the year 2050, due to titration of $\mathrm{O}_{3}$ mainly during winter time (see Sect. 3.2.3), and lower concentrations of $\mathrm{OH}$ due to the large increase of $\mathrm{CO}$. The emissions in the China region with respect to the year 2005 are expected to increase by $20 \%, 76 \%$ and $233 \%$ for $\mathrm{NO}_{\mathrm{x}}$ and $\sim 15 \%, \sim 40 \%$ and $\sim 65 \%$ for NMVOC for the years 2010 , 2025,2050 , respectively, largely during winter time. On the other hand, the relative increase of ozone with respect to the year 2005 (i.e. $1 \%, 10 \%$ and $16 \%$ as annual mean for the year 2010, 2025 and 2050, respectively) includes very strong seasonality: during winter the relative increase of ozone is lowest (i.e. $-1 \%, 2 \%$ and $6 \%$ for the year 2010, 2025 and 2050), indicating that substantial titration is taking place, while during summer the ozone relative difference with respect to the year 2005 is much higher, i.e. $2 \%, 12 \%$ and $28 \%$ for the year 2010, 2025 and 2050, respectively.

In most of Europe and eastern North America, ozone mixing ratios are not expected to change drastically, because the projected local precursor emission decreases will be coun-

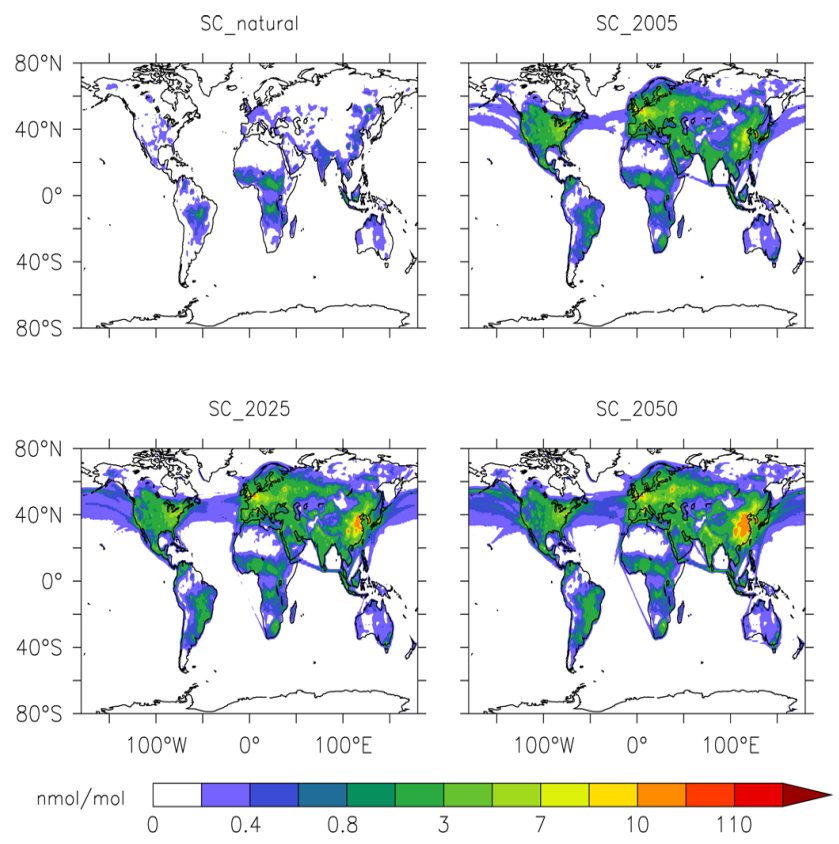

Fig. 5. Model calculated annual mean near-surface nitrogen dioxide in nmol mol ${ }^{-1}$ from simulation SC_natural, SC_2005, SC_2025 and SC_2050.

teracted by a hemispheric increase in background values (Lelieveld and Dentener, 2000). The titration over Europe during winter time (Wild and Prather, 2006) will be partially enhanced, as the emission of $\mathrm{NO}_{\mathrm{x}}$ over Western Europe is projected to increase (with respect to the year 2005) by $2 \%$, $7 \%$ and $13 \%$ for the years 2010, 2025 and 2050, respectively, while NMVOC emissions are expected to decrease by $2 \%, 12 \%$ and $20 \%$, respectively.

Overall, the tropospheric burden of ozone is calculated to increase by $15 \%$ between 2005 to 2050 , from 387 to $442 \mathrm{Tg}$ (Table 3).

\subsection{3 $\mathrm{NO}_{2}$}

As shown in Fig. 5, the increasing ship traffic noticeably affects the $\mathrm{NO}_{2}$ distributions in the different simulations. According to $S C_{2} 2005$ and $S C_{-} 2050$, air traffic emissions also increase substantially in this period, from $\sim 0.9$ to $\sim 1.4 \mathrm{Tg}(\mathrm{N}) \mathrm{yr}^{-1}$, while the ship emissions are expected to 

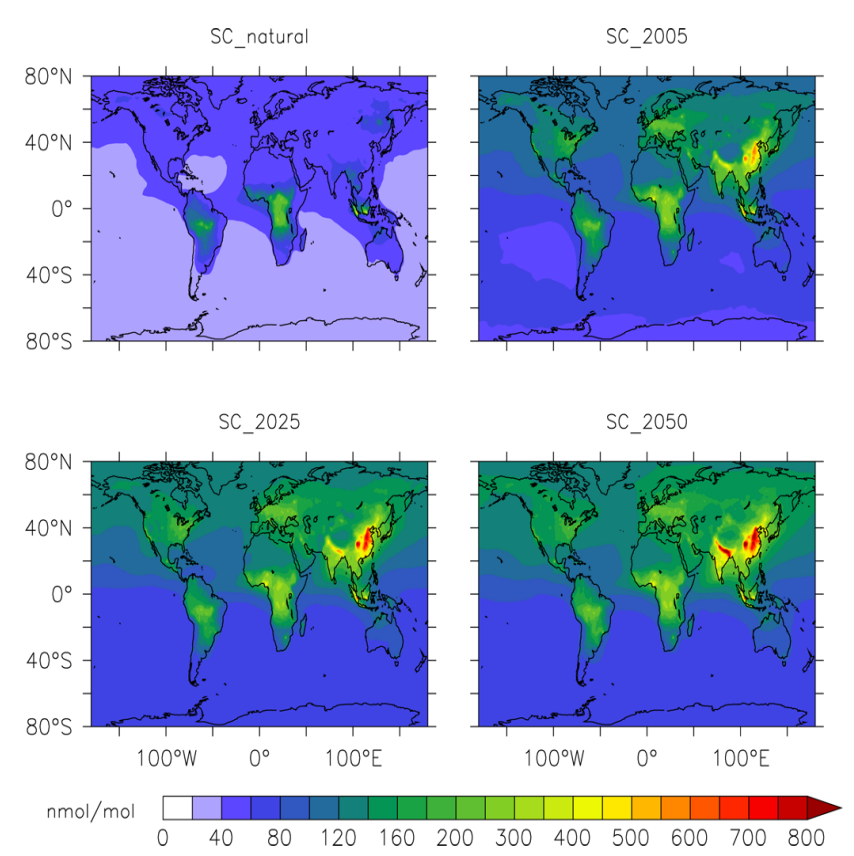

Fig. 6. Model calculated annual mean near-surface carbon monoxide in $\mathrm{nmol} \mathrm{mol}^{-1}$ from simulation SC_natural, SC_2005, SC_2025 and SC_2050.

increase from $\sim 4$ to $\sim 11 \mathrm{Tg}(\mathrm{N}) \mathrm{yr}^{-1}$. In contrast to $\mathrm{SO}_{2}$, in Europe and the eastern USA we find similar $\mathrm{NO}_{2}$ mixing ratios as in India. China is expected to become the most prominent $\mathrm{NO}_{\mathrm{x}}$ emitter and in future its near-surface mixing ratios of $\mathrm{NO}_{2}$ are projected to be the highest in the world, which contributes to ozone formation downwind. For example, over the central Pacific Ocean the annual mean near-surface mixing ratio of $\mathrm{O}_{3}$ is calculated to increase from less than 15 to nearly $50 \mathrm{nmol} \mathrm{mol}^{-1}$ from SC_natural to $S C \_2050$. The resultant ozone levels in China, close to the $\mathrm{NO}_{\mathrm{x}}$ sources, may not increase very strongly after 2005 (see Sect. 3.2.2) since the growing $\mathrm{NO}$ sources also cause a local tritation of $\mathrm{O}_{3}$.

\subsubsection{CO}

The atmospheric carbon monoxide burden almost doubles from simulation SC_natural to simulation SC_2005, increasing from $\sim 200$ to $393 \mathrm{Tg}$. Results from simulation SC_2050 indicate that the burden projected for the year 2050 will be $484 \mathrm{Tg}$, suggesting a $\sim 23 \%$ increase between 2005 and 2050. As shown in Fig. 6, the increasing emissions from SC_natural to SC_2005 influence the atmosphere globally, as the relatively long lifetime of $\mathrm{CO}$ (several months) allows efficient transport on large scales. While the peak increases in CO concentrations in SC 2050 relative to SC_2005 are located in the poor air quality hot spots of southern and eastern Asia, large effects are also found over remote regions, with substantially increasing mixing ratios over the northern Indian Ocean, the central Pacific Ocean, the central Atlantic Ocean and Siberia. The typical large scale contrast that appears between source regions and the background atmosphere in SC_natural decreases in SC_2005. This is a result of the global anthropogenic $\mathrm{CO}$ emissions which are not in phase with the biogenic and biomass burning emissions (see also the seasonal variability of the burden in Table 3). Hence the anthropogenic emissions damp the annual cycle and the horizontal contrast in CO mixing ratios. In the year 2050 the anthropogenic emissions are projected to substantially exceed the natural ones, so that the amplitude of the annual cycle (see Table 3 ) forced by the anthropogenic emissions is comparable to that in SC_natural.

\subsubsection{Hydroxyl radical $(\mathrm{OH})$}

The hydroxyl radical is the main oxidant in the troposphere and its average concentration determines the "cleansing capacity" of the atmosphere (Levy, 1971). In Fig. 7, the annual average of the $\mathrm{OH}$ radical concentration at the surface is shown for the different simulations performed. The highest concentrations are found in the tropics, as expected (Prinn et al., 1992; Spivakovsky et al., 2000). In all simulations the highest values are found over the tropical oceans. In this environment primary $\mathrm{OH}$ production is facilitated by the strong insolation together with the high abundance of water vapor. Over the tropical forest the $\mathrm{OH}$ present a minimum due to the strong emission of non methane volatile organic compounds (NMVOC), which deplete the available $\mathrm{OH}$. This is in contrast with the recent study of Taraborrelli et al. (2012), which shows that the $\mathrm{OH}$ recycling over tropical forest is very efficient, a process which has not been incorporated in this study.

In the simulations with anthropogenic emissions included, the highest annual average $\mathrm{OH}$ concentrations (up to $6 \times$ $10^{6} \mathrm{mcl} \mathrm{cm}^{-3}$ ) are found off the coast of South and East Asia, over the Gulf of Mexico and the Red Sea. The ship tracks are very pronounced with high $\mathrm{OH}$ levels, due to the localized $\mathrm{NO}_{\mathrm{x}}$ emissions in the otherwise relatively unpolluted environment, which enhance the recycling of $\mathrm{OH}$ (Lawrence and Crutzen, 1999; Lelieveld et al., 2002). Despite the high $\mathrm{OH}$ in ship tracks, in more remote regions over the tropical oceans $\mathrm{OH}$ levels have reduced, mostly due to the increasing methane. This is confirmed by the global average $\mathrm{OH}$ concentrations for the different simulations, presented in Table 4. Global $\mathrm{OH}$ is projected to reduce according to future scenarios, although not very significantly (Krol et al., 1998; Prinn et al., 2001). In general, OH concentrations over the tropical oceans respond relatively sensitively to anthropogenic perturbations (Lelieveld et al., 2002). Although the marine locations of relatively high $\mathrm{OH}$ in simulation $S C$ natural are still present in the simulations for 2005 up to 2050, the landocean contrasts are reduced due to enhanced $\mathrm{OH}$ production by $\mathrm{NO}_{\mathrm{x}}$ in continental locations. Global mean $\mathrm{OH}$ changes in the future will be dependent on the trade-off between enhanced $\mathrm{OH}$ production by $\mathrm{NO}_{\mathrm{x}}$, increased $\mathrm{O}_{3}$ formation, and $\mathrm{OH}$ reductions caused by growing concentrations of reactive carbon $\left(\mathrm{CH}_{4}, \mathrm{CO}\right.$, NMVOC). The relatively low latitude 

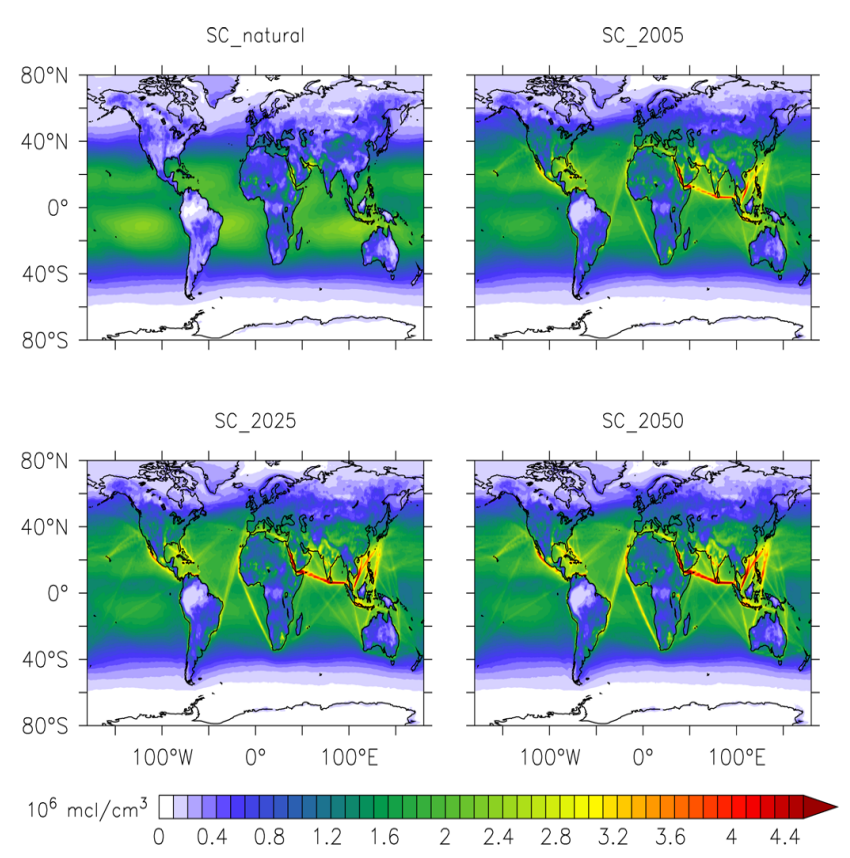

Fig. 7. Model calculated annual mean surface hydroxyl radical concentration in $10^{6} \mathrm{~cm}^{-3}$ from simulation SC_natural, SC_2005, SC_2025 and SC_2050.

location of India, combined with relatively high $\mathrm{NO}_{\mathrm{x}}$ and $\mathrm{O}_{3}$ levels, may cause this country to become a continental $\mathrm{OH}$ hot spot in future (see Fig. 7).

\subsection{6 $\mathrm{PM}_{2.5}$}

$\mathrm{PM}_{2.5}$ is very important for air quality, and its influence on human health is generally recognized (Brunekreef and Holgate, 2002, and reference therein). Even low levels of exposure have effects on the lungs and the cardiovascular system (Dockery, 2001).

Natural high level of $\mathrm{PM}_{2.5}\left(150-350 \mu \mathrm{g} \mathrm{yr}^{-1}\right)$ are found over desert regions (especially North Africa region) because of dust emissions, and over the Southern Ocean (10$20 \mu \mathrm{g} \mathrm{yr}^{-1}$ ), due to sea salt emissions. It must be stressed that $\mathrm{PM}_{2.5}$ is not only formed by bulk aerosol species, but also by the formation of secondary aerosol (Orel and Seinfeld, 1977) especially where direct emissions of precursors are very high. As shown in the Supplement, the anthropogenically emitted $\mathrm{BC}$ is projected to increase by only $\sim 25 \%$, while $\mathrm{SO}_{2}$ and $\mathrm{NO}_{\mathrm{x}}$ emissions are both projected to increase by a factor of two.

As shown in Fig. 8 the largest changes of $\mathrm{PM}_{2.5}$ between simulation SC_natural and SC_2005 are located in Europe, North East USA and particularly in southern and East Asia. In future scenarios (SC_2025 and SC_2050), the increase of $\mathrm{PM}_{2.5}$ is largest in East and South Asia, associated with the strong increase of aerosol and precursors emissions.

The absolute increase of $\mathrm{PM}_{2.5}$ between simulation SC_natural and SC_2050 over Europe and the eastern USA
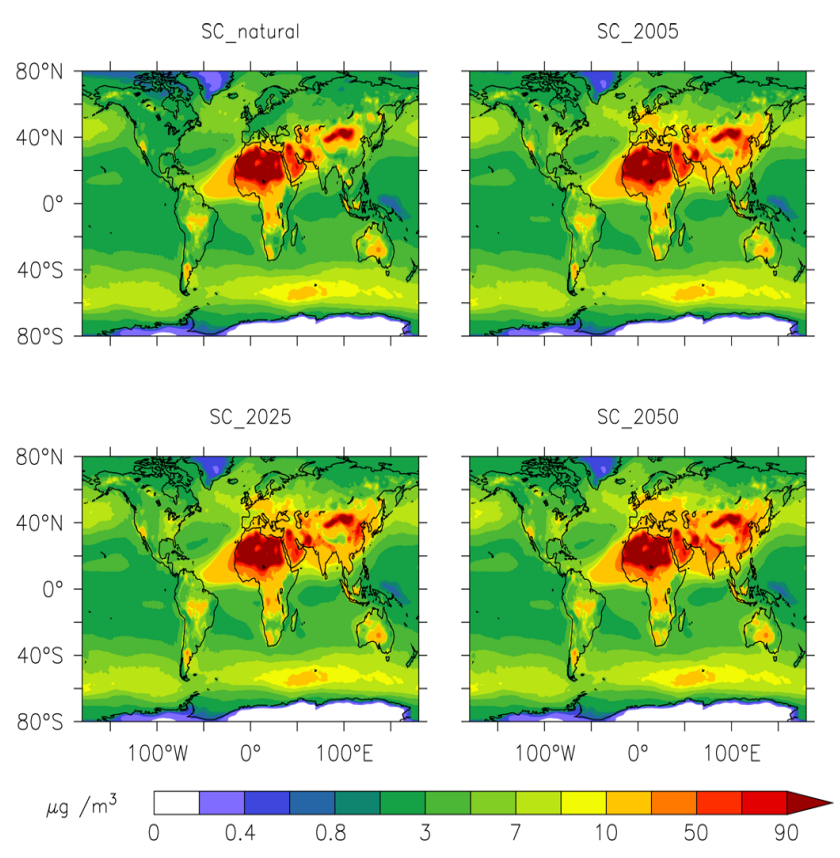

Fig. 8. Model calculated annual mean near-surface $\mathrm{PM}_{2.5}$ in $\mu \mathrm{g} \mathrm{m}^{-3}$ from simulation SC_natural, SC_2005, SC_2025 and SC_2050.

$\left(\sim 30 \mu \mathrm{g} \mathrm{m}^{-3}\right)$ are lower in magnitude than what can occur naturally over some desert areas (up to $\sim 350 \mu \mathrm{g} \mathrm{m}^{-3}$ yearly averaged), and is comparable to $\mathrm{PM}_{2.5}$ present in the pristine region of the Southern Ocean. Although this increase may hence appear not significant and lower than natural concentrations in many areas of the world, the relative increase is between a factor of 2 to 6 compared to pre-industrial conditions. Higher increases of $\mathrm{PM}_{2.5}$ are projected in China and northern India in simulation SC 2050. These increases, added to the already present natural $\mathrm{PM}_{2.5}$, will lead to concentrations similar to desert areas, with a 10 fold relative increase with respect to pre-industrial conditions.

\section{Multi pollutant index}

\subsection{General definition}

As we are focusing on multiple gases and aerosols which are harmful to human health, it is useful to combine these into a single index of air quality. Different indices are presented in the literature, and a comprehensive review can be found in Plaia and Ruggieri (2011). We selected the multipollutant index (MPI) as defined by Gurjar et al. (2008) because it was tested for the representation of long term air quality (Gurjar et al., 2008), and hence is appropriate to be used with annual average data. It must be stressed that the MPI is a linear index of air quality related to health and does not do justice to exponential influences related to the exposure time and synergies associated with the effects of multiple pollutants. 
Table 4. Global average tropospheric $\mathrm{OH}$ concentration in $10^{6} \mathrm{~cm}^{3}$, estimated with different weightings (mass, volume, methyl chloroform reaction and methane reaction) factors for the different simulations presented in this work. S2000 is the same calculation from the work of Spivakovsky et al. (2000).

\begin{tabular}{l|c|cc|cc|c}
\hline method & S2000 & SC_natural & SC_2005 & SC_2010 & $S C \_2025$ & $S C \_2050$ \\
\hline mass & 1.14 & 1.16 & 1.07 & 1.07 & 1.04 & 1.04 \\
volume & 1.10 & 1.19 & 1.07 & 1.07 & 1.04 & 1.03 \\
$k_{\mathrm{MCF}}$ & 1.29 & 1.30 & 1.23 & 1.24 & 1.21 & 1.21 \\
$k_{\mathrm{CH}}$ & 1.32 & 1.28 & 1.21 & 1.22 & 1.19 & 1.18 \\
\hline
\end{tabular}

Following the approach of Gurjar et al. (2008), an MPI can be defined as:

$\mathrm{MPI}=(1 / n)\left[\sum\left(\mathrm{AC}_{i}-\mathrm{GC}_{i}\right) / \mathrm{GC}_{i}\right]$

where $n$ is the total number of pollutants taken in consideration, $\mathrm{AC}_{i}$ is the atmospheric concentration of a pollutant in a certain location and $\mathrm{CG}_{i}$ is the guideline concentration of a pollutant recommended by a national or international agency such as the WHO (World Health Organization - Regional Office for Europe, 1987, 2000; World Health Organization, 2005). As shown by Gurjar et al. (2008), a clean environment (in the absence of air pollutants) has an MPI equal to -1 , while for a location with $\mathrm{AC}_{i}$ equal to the $\mathrm{CG}_{i}$ (i.e. a location with borderline air quality), the MPI would be around 0 . No upper limit is given for the MPI, with relatively higher values corresponding to poorer air quality. We refer to Gurjar et al. (2008) for a detailed discussion on this index.

As mentioned in Sect. 3, in this work only the annual average values are taken into account. Different recommendations and air quality standards for annual averages have been published in the past decades (i.e. World Health Organization - Regional Office for Europe, 1987, 2000; World Health Organization, 2005), reflecting the evolving understanding about the impact of long term exposure to these compounds on human health (Krzyzanowski and Cohen, 2008; HTAP, 2010). For example, the WHO recently abandoned the guideline limit value for particulate matter, reflecting that there is no "safe" lower threshold for this pollutant. Notwithstanding this discussion and the specific interpretation of the WHO air quality standard on regional and national levels, we adopted the limits as defined by Gurjar et al. (2008) for $\mathrm{SO}_{2}\left(17 \mathrm{nmol} \mathrm{mol}^{-1}\right)$ and $\mathrm{NO}_{2}\left(20 \mathrm{nmol} \mathrm{mol}^{-1}\right)$, for consistency with this work, while for $\mathrm{PM}_{2.5}$, the lowest level suggested by the WHO $\left(10 \mu \mathrm{m}^{-3}\right)$ is used. For $\mathrm{O}_{3}$ and $\mathrm{CO}$ only hourly recommendations are generally given. For $\mathrm{NO}_{2}$, the ratio between hourly and annual WHO recommendation (200 and $40 \mu \mathrm{m}^{-3}$, respectively) is one fifth Hence we used the same ratio to scale the hourly recommendation for $\mathrm{CO}$ (i.e. $7000 \mathrm{nmol} \mathrm{mol}^{-1}$, from the WHO recommendation, World Health Organization, 2005) and for $\mathrm{O}_{3}$ (i.e. $24 \mathrm{nmolmol}^{-1}$, from the EPA recommendation, EPA, 2005). As mentioned before, although these values cannot quantitatively reflect the health risk associated with the exposure to mixtures of pollutants (which depends strongly on the compounds selected), we believe it provides an objective metric to compare air pollution in different regions, based on our model output. Additionally, following the discussions in Sect. 3, we did not use $\mathrm{NO}_{2}$ or $\mathrm{O}_{3}$, but rather the combination of the two gas tracers $\left(\mathrm{O}_{\mathrm{x}}\right)$, which is well represented in the model. The air quality limits thus used are $10 \mu \mathrm{m}^{-3}$ for $\mathrm{PM}_{2.5}, 17,44$ and $7000 \mathrm{nmol} \mathrm{mol}^{-1}$ for $\mathrm{SO}_{2}, \mathrm{O}_{\mathrm{x}}$ and $\mathrm{CO}$, respectively. It must also be stressed that the MPI values are strongly influenced by the value used for $\mathrm{CG}_{i}$ (recommended concentrations). In this work, the $\mathrm{PM}_{2.5}$ has the strongest influence on the overall MPI value, while CO has the least influence, due to its annual value generally being much lower than $7000 \mathrm{nmol} \mathrm{mol}^{-1}$. Hence, the MPI definition must be used carefully with respect to the absolute values, while it is more robust when used to compare different locations in time and space.

In Fig. 9, the MPI values for the preindustrial case and for the year 2005 are presented. Not surprisingly, locations that are strongly influenced by desert dust have a very high MPI (i.e. low air quality), while even the pristine marine environment has a reduced (though not poor) air quality due to sea spray. The desert dust areas include northern Africa, the Arabian Peninsula, the region east of the Persian Gulf, northern China (influenced by the Gobi desert) and central Australia. The influence of anthropogenic emissions is apparent in simulation SC_2005, especially over China and northern India, where the strong emissions of pollutants bring the annual MPI close to 1.0.

In Figs. 10 and 11 the differences between the MPIs from the four recent and future simulations (SC_2005, SC_2010, $S C \_2025, S C \_2050$ ) and the MPI obtained for the "preindustrial case" (SC_natural) are presented. In the year 2005, five or six main regions of decreased air quality due to anthropogenic emissions emerge: North America (east and west coast), Europe and the Mediterranean Basin, the Middle East, India and eastern China. In recent years, i.e. between 2005 and 2010, air quality noticeably degraded in the latter regions, especially in China.

In the projections for the future periods several regions with very high MPIs become apparent, mainly by the 


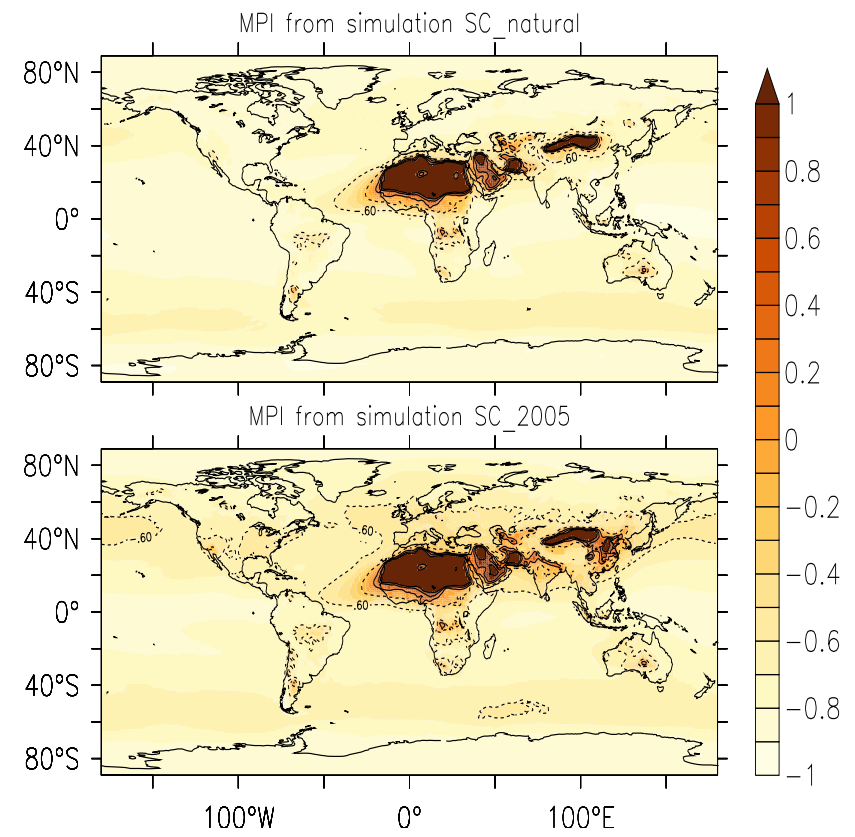

Fig. 9. Multi Pollutant Index (MPI) as calculated from simulation SC_natural and from simulation SC_2005. The contours are shown at multiples of 0.4 .

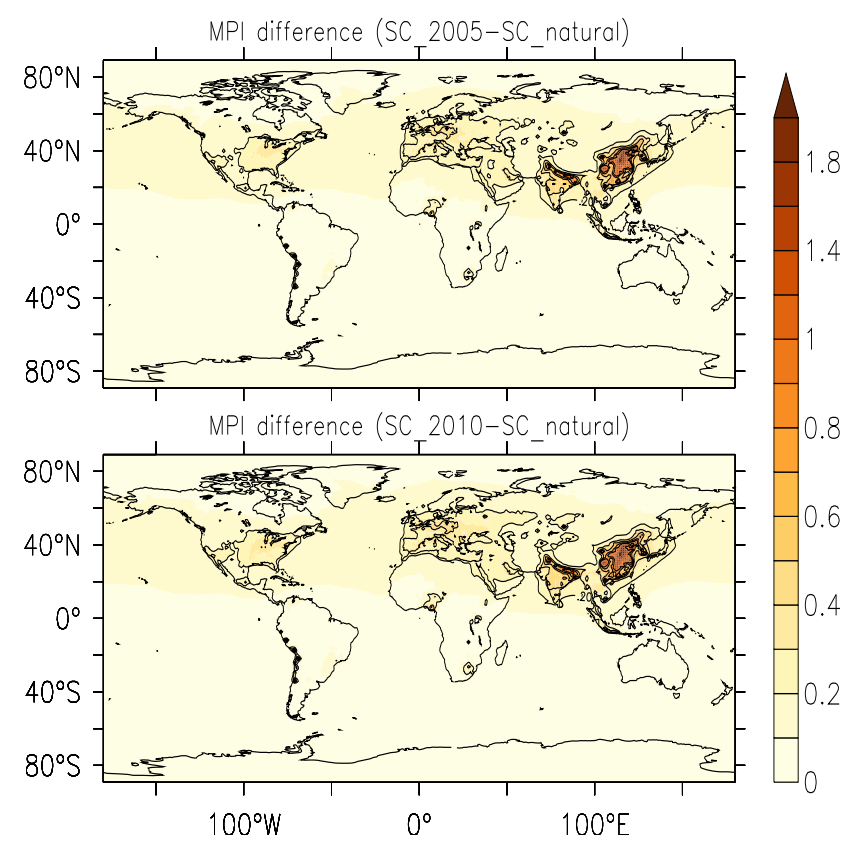

Fig. 10. Difference between the MPI estimated from simulations SC_2005 and SC_2010 and the MPI calculated from simulation $S C \_n a t u r a l$. The contours are shown at multiples of 0.2 up to the level of 1 .

expansion of the present ones. Anthropogenic emissions will continue to degrade air quality in eastern China in 2025 with an MPI increase in excess of one full point in the northeast, while northern India is also emerging with high MPIs. The

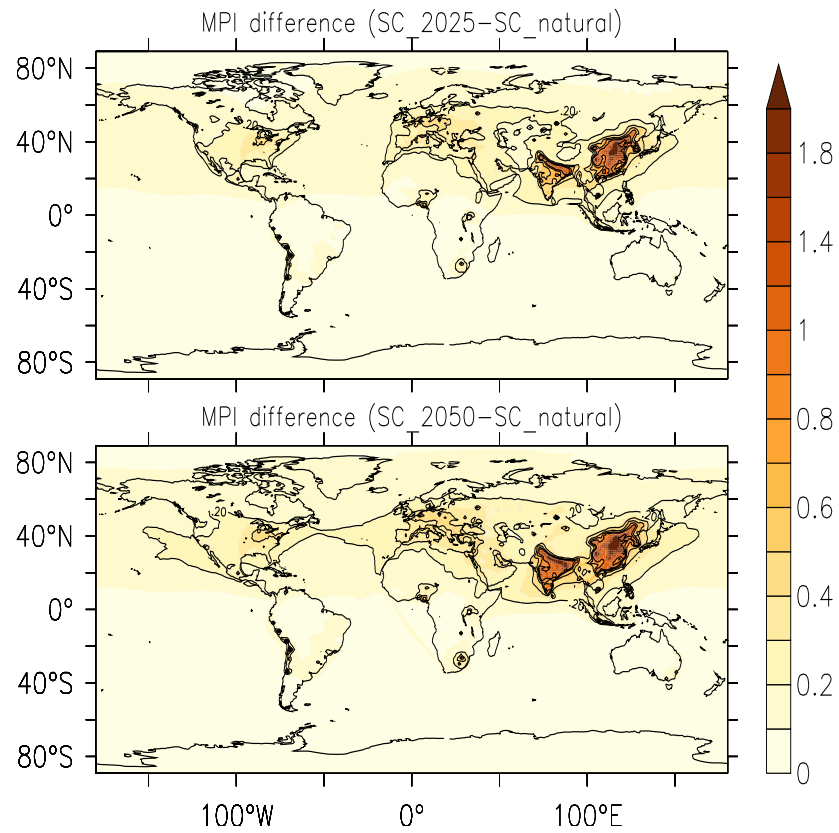

Fig. 11. Difference between the MPI estimated from simulations $S C_{-} 2025$ and SC_2050 and the MPI calculated from simulation $S C \_n a t u r a l$. The contours are shown at multiples of 0.2 up to the level of 1.

northeastern USA, Central East Europe and the Middle East also appear as high MPI regions, though with lower MPI values than the Asian regions. The increase of MPI due to anthropogenic emissions in the Middle East and North Africa has to be added to the already high MPI by natural causes present in these regions, leading to very high MPIs. The main cause of the increase of the MPI in the Middle East is the formation of photochemical smog with high ozone levels. In contrast, in India and China particulate matter and $\mathrm{SO}_{2}$ play an important role.

The large scale influence of these emerging anthropogenic air-pollution hot spots is shown in Fig. 11, illustrating that intercontinental "connections" are formed. These are mostly due to intercontinental transport from land sources, as the influence of the ship emissions on the MPI is rather limited, being several orders of magnitude lower than the emissions over land. The increased MPI regions ( $>0.2$ increase with respect to the natural conditions) extend across the entire Northern Hemisphere, especially in the middle and subtropical latitudes, including the USA and the Mediterranean Basin. In India the MPI is additionally enhanced by growing $\mathrm{O}_{3}$ and $\mathrm{PM}_{2.5}$ pollution, while in China the high levels of $\mathrm{NO}_{2}, \mathrm{SO}_{2}$ and $\mathrm{PM}_{2.5}$ contribute substantially. 


\subsection{Population weighted MPI}

\subsubsection{Definition}

Although the MPI helps in defining the degradation of air quality in polluted regions, it does not account for the numbers of people subjected to these conditions. Typically, polluted regions are also densely populated, in particular in the urban environment. Following the approach introduced in the previous section, we defined the Population Weighted Multi Pollutant Index (PW-MPI), thus extending the definition to include population density. We used the (normalised) human population estimate to define a weighting factor to the MPI in the calculations:

PW-MPI $=\frac{1}{W} \sum_{i=1}^{N} w_{i}$ MPI $_{i}$

where $w_{i}$ is the weighting factor (the population in a certain model grid), $W=\sum_{i=1}^{N} w_{i}$ is the normalisation factor (the total population in the area) and $i=1 \ldots N$ refers to the model grid box in the region of interest. According to this method, the index is not only proportional to the air quality level (with respect to the international recommendations) but also weighs the number of people that is subjected to it. One feature is that the PW-MPI offers the possibility of assessing the air quality on a global scale, over large regions and of countries, as the index reflects the mean level air quality to which the average person is subjected. To calculate the weighting factors, we used the population estimates for the year 2005, 2010, 2025 and 2050 by the Center for International Earth Science Information Network (CIESIN). For the $S C$ natural simulation the weighting factors are based on the year 2005 population for reference. This population weighting is a standard approach, also used by Brauer et al. (2012) focusing on ozone and $\mathrm{PM}_{2.5}$.

\subsubsection{PW-MPI by regions}

In Table 5 the PW-MPI index is presented globally and for seven regions of interest: North America, Europe, Middle East, East Asia, South Asia, Central Africa and South America (see Fig. 12 for the region boundaries and Fig. 13 for a visual summary).

The largest apparent changes in the PW-MPI occur between simulation $S C$ natural and SC_2005, related to growing air pollution in the 19th and 20th centuries, which rather drastically impacted air quality for much of the world population.

Although the PW-MPI changes between SC_2005 and SC_2050, may seem smaller than those up to 2005, they occur on a shorter time scale. For North and South America, Europe and Central Africa the rate of air quality degradation is gradual. For the economically emerging regions in South and East Asia and the Middle East the PW-MPI increases in the 21 st century are rapid.

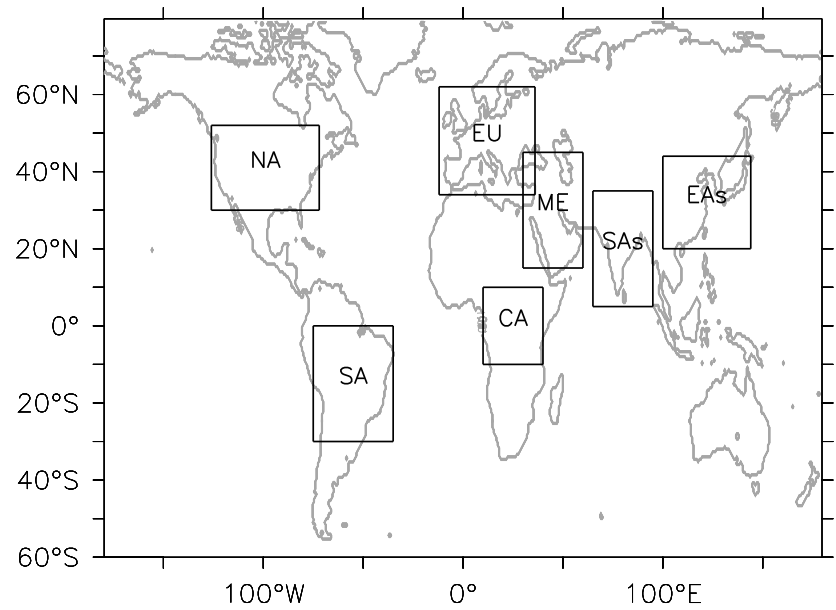

Fig. 12. Location and extension of the geographical regions used in the PW-MPI calculation. The regions are: North America (NA), Europe (EU), East Asia (EAs), South Asia (SAs), Central Africa (CA) and South America (SA).

Globally, the PW-MPI increased by $\sim 80 \%$ between SC_natural and SC_2005, and an additional factor of two rise is projected up to the year 2050 . The increase of $\sim 80 \%$ is a lower limit, as we neglected the urbanisation from preindustrial to 2005, using the same population distribution in both cases. North America and Europe have developed (and will continue to develop) very similarly, presumably typical for countries that have rapidly industrialised in the 20th century. After a strong increase of the PW-MPI since preindustrial conditions (by $\sim 0.3-0.4$ ), the projected changes up to the year 2050 will be much smaller (around $25 \%$ ) in these regions compared to the globally projected changes. Even though air quality will deteriorate further in North America and Europe, in 2050 it will be significantly better than that experienced by the global average citizen. Remarkably, the global PW-MPI in 2050 is projected to be similar to that in the Middle East in the year 2005.

It should be emphasized that this result is strongly influenced by the high population density in Asia (i.e. poor air quality affecting a large number of people). In fact, East and South Asia both have the highest MPI values (see Fig. 9) and the highest population densities. The PW-MPI for East Asia has strongly increased from -0.71 to 0.30 between SC_natural and SC_2005, more strongly than the increases experienced by any other region. Interestingly, all regions except the Middle East have a similar PW-MPI under nonanthropogenically polluted conditions (SC_natural), while in simulation SC_2050 East and South Asia, closely followed by the Middle East, are projected to have much higher PWMPIs, up to 0.82 (Table 5). The projected changes in air quality in East and South Asia are so drastic $(\sim 0.5-0.7$ difference between $S C_{2} 2050$ and $S C_{2}$ 2005) and the population densities so high that the global PW-MPI is strongly influenced. South Asia (i.e. India) is the region experiencing the largest 
Table 5. PW-MPI values for selected regions.

\begin{tabular}{llrrrrr}
\hline region & region boundaries & SC_natural & SC_2005 & SC_2010 & SC_2025 & SC_2050 \\
\hline global & & -0.63 & -0.13 & -0.09 & 0.01 & 0.18 \\
North America & $126-72^{\circ} \mathrm{W} ; 30-52^{\circ} \mathrm{N}$ & -0.81 & -0.50 & -0.49 & -0.47 & -0.43 \\
Europe & $12^{\circ} \mathrm{W}-36^{\circ} \mathrm{E} ; 34-62^{\circ} \mathrm{N}$ & -0.77 & -0.42 & -0.41 & -0.39 & -0.34 \\
Middle East & $30-60^{\circ} \mathrm{E} ; 15-45^{\circ} \mathrm{N}$ & -0.02 & 0.22 & 0.23 & 0.32 & 0.46 \\
East Asia & $100-144^{\circ} \mathrm{E} ; 20-44^{\circ} \mathrm{N}$ & -0.71 & 0.30 & 0.39 & 0.62 & 0.82 \\
South Asia & $65-95^{\circ} \mathrm{E} ; 5-35^{\circ} \mathrm{N}$ & -0.64 & -0.05 & -0.02 & 0.16 & 0.70 \\
Central Africa & $10-40^{\circ} \mathrm{E} ; 10^{\circ} \mathrm{S}-10^{\circ} \mathrm{N}$ & -0.57 & -0.45 & -0.44 & -0.42 & -0.40 \\
South America & $75-35^{\circ} \mathrm{W} ; 30^{\circ} \mathrm{S}-0^{\circ} \mathrm{N}$ & -0.80 & -0.69 & -0.68 & -0.66 & -0.63 \\
\hline
\end{tabular}

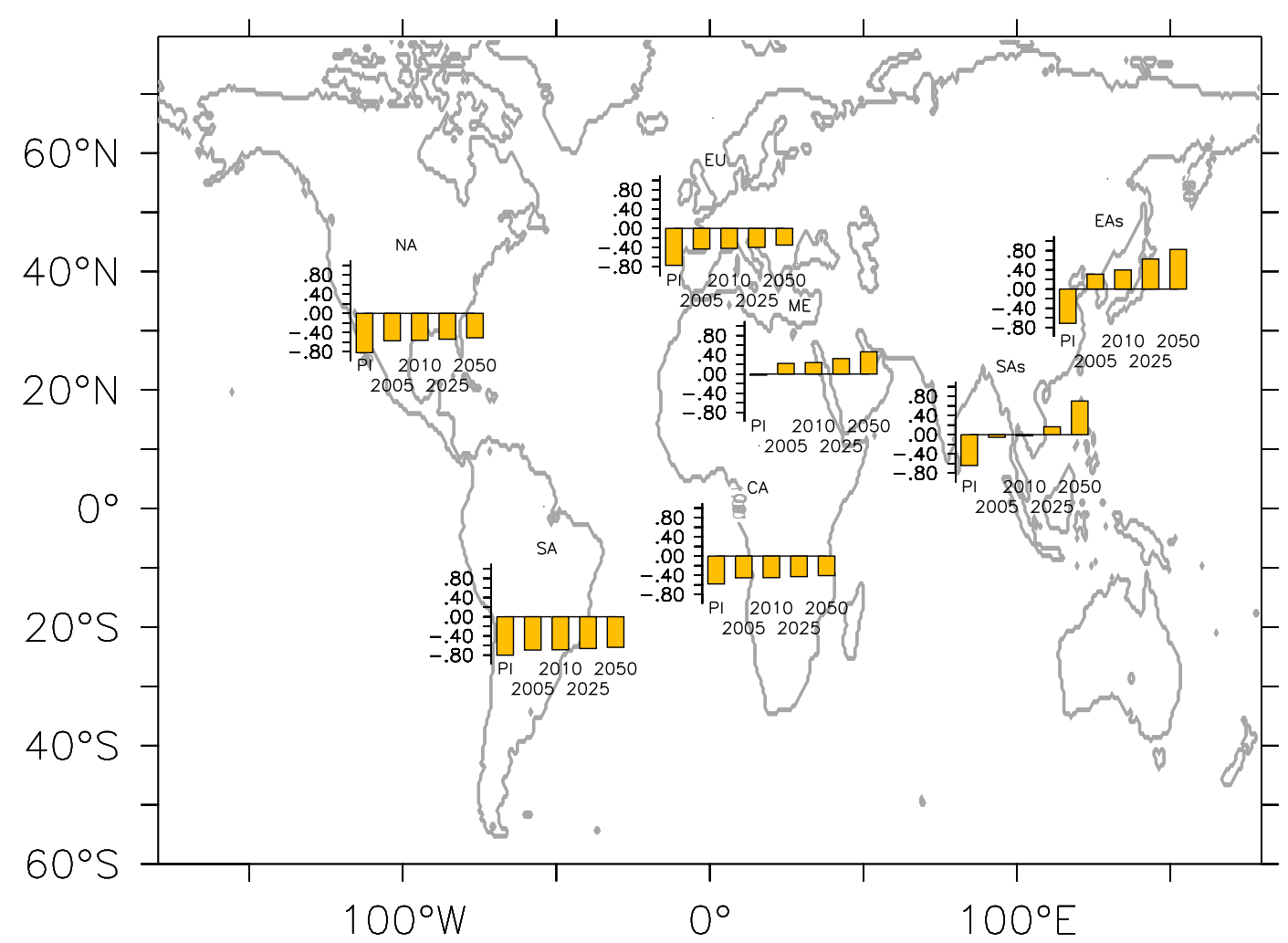

Fig. 13. Population Weighted Multi Pollutant Index (PW-MPI) values for different regions. This figure summarises Table 5. The regions are: North America (NA), South America (SA), Europe (EU), Middle East (ME), Central Africa (CE), South Asia (SAs) and East Asia (EAs).

changes between simulations SC_2005 and SC_2050 with an increase of 0.75 , by far the largest of all regions. Impressively, this change is even larger than the PW-MPI change between $S C \_2005$ and $S C \_n a t u r a l(\sim 0.6)$.

Finally, the Middle East is a hot spot of poor air quality, for which we calculated a PW-MPI change between $S C \_2005$ and $S C \_2050$ equal to the PW-MPI change between $S C \_2005$ and $S C$ _natural (i.e. $\sim 0.2)$. However, the high abundance of desert dust and the consequently low air quality since preindustrial times and the continuous industrialisation (mainly related to the oil extraction and processing industry) will drastically degrade the atmospheric environmental conditions.

In Central Africa the PW-MPI values are close to those in North America. This is due to the particular population distribution and the fact that some subregions are strongly influenced by desert dust. The best air quality and the lowest PW-MPIs are calculated for South America, although also in this region pollution conditions are gradually becoming worse. The projected PW-MPI is estimated to remain lower compared to all other regions during the entire period 2005 2050 . 


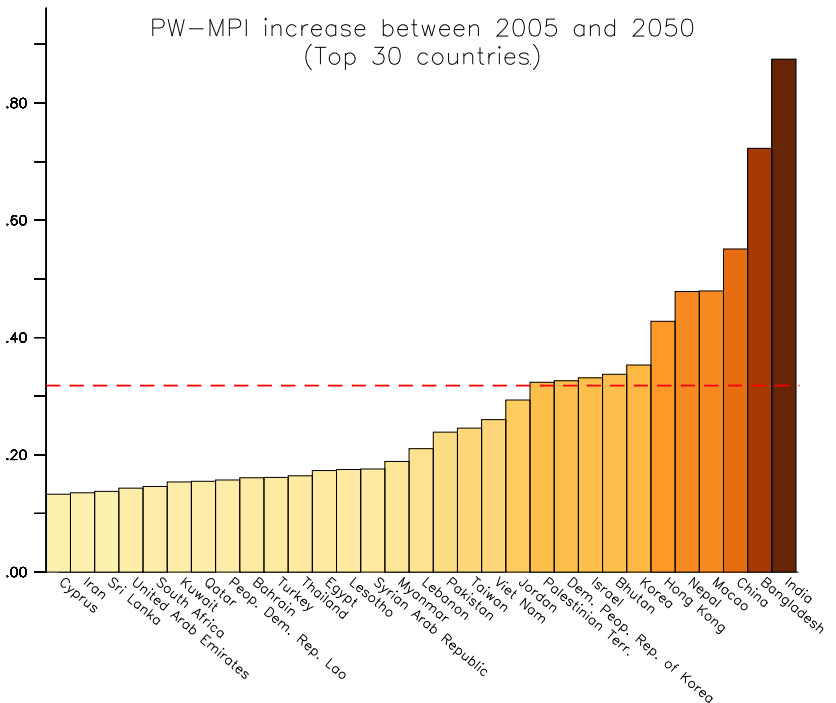

Fig. 14. PW-MPI changes between 2005 and 2050 for different countries (30 countries with the strongest changes). The red dashed line depicts the global PW-MPI increase between 2005 and 2050.

\subsubsection{PW-MPI by country}

In Table 6 the PW-MPI is presented for the 100 world countries with the highest PW-MPI in 2005. The complete list is available in the Supplement. Countries with a high abundance of natural desert dust are ranked high in the list due to the strong influence of $\mathrm{PM}_{2.5}$ in the PW-MPI calculations. It is interesting to notice the changes over time of the PWMPI for different countries. As shown in Fig. 14, India is projected to have the most rapid degradation of air quality, followed by Bangladesh and China. Figure 14 also includes many countries in the Middle East, which have poor air quality already in simulation SC_2005. Finally, although the PWMPI is projected to increase globally by $\sim 0.31$, most countries will face a much lower increase. A very few densely populated countries such as China, India and Bangladesh, on the other hand, are expected to be affected by a much higher increase (almost twice as high).

\section{Conclusions}

We used the global EMAC model to estimate the potential impact of anthropogenic emission changes on air quality in recent and future years (2005, 2010, 2025 and 2050), based on a "business as usual" scenario. No feedbacks between the changing atmospheric composition and dynamics were allowed in the GCM, so that the model simulated air quality is controlled by air pollution emissions rather than climate change, though the latter may be an additional important factor in the future atmospheric composition (Giorgi and Meleux, 2007; Jacob and Winner, 2009; Dawson et al., 2009).
We focussed on the five major pollutants that impact human health: $\mathrm{PM}_{2.5}$, nitrogen dioxide $\left(\mathrm{NO}_{2}\right)$, sulphur dioxide $\left(\mathrm{SO}_{2}\right)$, ozone $\left(\mathrm{O}_{3}\right)$ and carbon monoxide $(\mathrm{CO})$.

The model reproduces the main characteristics of recent air quality according to observations in North America, eastern Asia and Europe, although with some imprecisions inherent to the coarse resolution of the model. Evaluation of the model results indicates that near the surface the model underestimates $\mathrm{CO}$ and $\mathrm{NO}_{2}$ mixing ratios. On the other hand, $\mathrm{SO}_{2}$ is slightly overestimated over Europe and Asia and underestimated over the USA, though the annual means are within $40 \%$ of the observations.

Both $\mathrm{O}_{3}$ and $\mathrm{PM}_{2.5}$ are simulated in reasonably good agreement with observations. While $\mathrm{NO}_{2}$ is underestimated, the calculated total oxidant $\mathrm{O}_{\mathrm{x}}$, (i.e. the sum of $\mathrm{O}_{3}$ and $\mathrm{NO}_{2}$ ) agrees well with observations with more than $56 \%$ of the model results being within $20 \%$ of the observations and $100 \%$ within a factor of two.

The simulations for the year 2025 and 2050 suggest that East Asia will be exposed to high levels of a range of pollutants $\left(\mathrm{SO}_{2}, \mathrm{NO}_{2}, \mathrm{PM}_{2.5}\right)$, though ozone may not increase very strongly. In contrast, in northern India and the Persian Gulf region, ozone levels may grow rapidly. To quantify the possible future air quality hot spots, a multi pollutant index (MPI) was introduced. This index, applied to the model projections, point to three main hot spots of poorest air quality in the future, located in eastern China, northern India and the Middle East/North Africa.

By weighting the MPI definition by population data, a Population Weighted MPI (PW-MPI) has been derived. The PW-MPI calculations indicate that global air quality has deteriorated significantly since pre-industrial times, which is projected to continue in the future. In 2050, most of the world population will be subjected to degraded air quality. The densely populated parts of South and East Asia contribute strongly to the loss of air quality for the average global citizen. The air quality (PW-MPI) in 2025 and 2050 is projected to be worst in the Middle East and North Africa, due to a combination of natural desert dust and anthropogenic ozone, followed by East and South Asia where anthropogenic pollution emissions will be particularly high.

It must be stressed that the results obtained in this work are based on a business as usual scenario. This rather pessimistic though plausible scenario represents a future where no additional climate change and air pollution reduction policies will be implemented using the year 2005 as a starting point. The results of this work indicate that strong actions and further legislations are essential to avoid a drastic deterioration of air quality which can have severe effects on human health.

\author{
Supplementary material related to this article is \\ available online at: http://www.atmos-chem-phys.net/12/ \\ 6915/2012/acp-12-6915-2012-supplement.pdf.
}


Table 6. PW-MPI values for different counties (ranked according to the PW-MPI in SC_2005, top 100 countries).

\begin{tabular}{|c|c|c|c|c|c|c|c|c|c|c|c|}
\hline country & SC_natural & $S C \_2005$ & SC_2010 & $S C \_2025$ & $S C \_2050$ & country & SC_natural & SC_2005 & SC_2010 & $S C_{-} 2025$ & SC_2050 \\
\hline Niger & 1.38 & 1.51 & 1.52 & 1.55 & 1.57 & Yemen & -0.41 & -0.23 & -0.22 & -0.19 & -0.12 \\
\hline Mauritania & 1.21 & 1.30 & 1.29 & 1.30 & 1.33 & Uzbekistan & -0.50 & -0.26 & -0.24 & -0.21 & -0.16 \\
\hline Chad & 1.12 & 1.21 & 1.21 & 1.23 & 1.25 & Eritrea & -0.40 & -0.26 & -0.25 & -0.22 & -0.17 \\
\hline Egypt & 0.67 & 0.94 & 0.95 & 1.01 & 1.11 & Netherlands & -0.83 & -0.27 & -0.27 & -0.25 & -0.21 \\
\hline Iraq & 0.44 & 0.70 & 0.70 & 0.73 & 0.82 & Ivory Coast & -0.35 & -0.28 & -0.28 & -0.26 & -0.24 \\
\hline Mali & 0.54 & 0.62 & 0.61 & 0.63 & 0.65 & Mongolia & -0.43 & -0.30 & -0.30 & -0.27 & -0.23 \\
\hline Libyan Arab Jamahiriya & 0.42 & 0.61 & 0.62 & 0.63 & 0.67 & Myanmar & -0.70 & -0.34 & -0.32 & -0.24 & -0.15 \\
\hline Kuwait & 0.21 & 0.57 & 0.57 & 0.60 & 0.72 & Greece & -0.66 & -0.35 & -0.34 & -0.33 & -0.27 \\
\hline Saudi Arabia & 0.34 & 0.56 & 0.56 & 0.59 & 0.66 & Bulgaria & -0.73 & -0.35 & -0.32 & -0.33 & -0.24 \\
\hline Nigeria & 0.20 & 0.52 & 0.52 & 0.58 & 0.59 & Dem. Rep. Congo & -0.45 & -0.36 & -0.36 & -0.35 & -0.34 \\
\hline Sudan & 0.35 & 0.46 & 0.46 & 0.48 & 0.52 & Chile & -0.79 & -0.38 & -0.35 & -0.32 & -0.29 \\
\hline United Arab Emirates & 0.16 & 0.44 & 0.44 & 0.49 & 0.59 & Tajikistan & -0.60 & -0.38 & -0.37 & -0.34 & -0.29 \\
\hline Bahrain & 0.04 & 0.40 & 0.40 & 0.44 & 0.56 & Cambodia & -0.68 & -0.38 & -0.37 & -0.32 & -0.30 \\
\hline Burkina Faso & 0.30 & 0.40 & 0.41 & 0.43 & 0.45 & Kyrgyz. Republic & -0.56 & -0.38 & -0.37 & -0.34 & -0.29 \\
\hline Senegal & 0.29 & 0.39 & 0.39 & 0.42 & 0.45 & Cyprus & -0.62 & -0.38 & -0.37 & -0.32 & -0.25 \\
\hline China & -0.69 & 0.37 & 0.47 & 0.71 & 0.92 & Czech Republic & -0.83 & -0.39 & -0.38 & -0.37 & -0.34 \\
\hline Qatar & 0.01 & 0.36 & 0.35 & 0.40 & 0.51 & Italy & -0.74 & -0.39 & -0.38 & -0.37 & -0.33 \\
\hline Pakistan & -0.28 & 0.29 & 0.29 & 0.40 & 0.53 & Gibraltar & -0.67 & -0.40 & -0.39 & -0.36 & -0.31 \\
\hline Gambia & 0.16 & 0.25 & 0.25 & 0.27 & 0.30 & Turkey & -0.67 & -0.40 & -0.38 & -0.32 & -0.24 \\
\hline Syrian Arab Republic & -0.05 & 0.19 & 0.21 & 0.27 & 0.37 & Albania & -0.69 & -0.40 & -0.38 & -0.38 & -0.32 \\
\hline Jordan & -0.15 & 0.18 & 0.20 & 0.30 & 0.47 & Poland & -0.84 & -0.40 & -0.38 & -0.38 & -0.36 \\
\hline Guinea-Bissau & 0.08 & 0.16 & 0.17 & 0.18 & 0.21 & Indonesia & -0.75 & -0.40 & -0.40 & -0.32 & -0.28 \\
\hline Cameroon & 0.04 & 0.16 & 0.16 & 0.19 & 0.20 & San Marino & -0.77 & -0.40 & -0.39 & -0.38 & -0.34 \\
\hline Palestinian Terr. & -0.20 & 0.13 & 0.16 & 0.27 & 0.46 & Liberia & -0.48 & -0.42 & -0.41 & -0.39 & -0.38 \\
\hline Korea & -0.76 & 0.11 & 0.18 & 0.33 & 0.46 & Taiwan & -0.80 & -0.42 & -0.37 & -0.27 & -0.17 \\
\hline Turkmenistan & -0.05 & 0.08 & 0.09 & 0.11 & 0.15 & Azerbaijan & -0.61 & -0.42 & -0.42 & -0.38 & -0.32 \\
\hline Macao & -0.79 & 0.07 & 0.15 & 0.35 & 0.55 & Slovenia & -0.79 & -0.42 & -0.40 & -0.39 & -0.35 \\
\hline Israel & -0.29 & 0.05 & 0.07 & 0.19 & 0.38 & Macedonia & -0.72 & -0.42 & -0.40 & -0.40 & -0.34 \\
\hline Hong Kong & -0.79 & 0.02 & 0.10 & 0.28 & 0.45 & Germany & -0.84 & -0.42 & -0.42 & -0.40 & -0.37 \\
\hline Algeria & -0.19 & 0.02 & 0.03 & 0.06 & 0.09 & Thailand & -0.76 & -0.42 & -0.41 & -0.32 & -0.26 \\
\hline Guinea & -0.06 & 0.01 & 0.01 & 0.03 & 0.05 & Japan & -0.79 & -0.42 & -0.41 & -0.38 & -0.35 \\
\hline Benin & -0.15 & -0.01 & -0.00 & 0.01 & 0.03 & Slovakia & -0.81 & -0.43 & -0.40 & -0.39 & -0.36 \\
\hline Cape Verde & -0.13 & -0.01 & -0.00 & 0.01 & 0.04 & Kazakhstan & -0.62 & -0.43 & -0.41 & -0.38 & -0.33 \\
\hline Togo & -0.13 & -0.02 & -0.02 & 0.00 & 0.02 & Spain & -0.75 & -0.43 & -0.43 & -0.41 & -0.37 \\
\hline Oman & -0.23 & -0.03 & -0.03 & 0.00 & 0.07 & Croatia & -0.77 & -0.44 & -0.42 & -0.41 & -0.36 \\
\hline Central African Republic & -0.11 & -0.06 & -0.06 & -0.05 & -0.03 & Hungary & -0.81 & -0.45 & -0.42 & -0.41 & -0.37 \\
\hline Bangladesh & -0.75 & -0.08 & -0.05 & 0.14 & 0.64 & Peop. Dem. Rep. Lao & -0.74 & -0.45 & -0.43 & -0.36 & -0.29 \\
\hline Iran & -0.30 & -0.08 & -0.07 & -0.04 & 0.05 & Austria & -0.82 & -0.45 & -0.44 & -0.42 & -0.39 \\
\hline India & -0.67 & -0.08 & -0.04 & 0.15 & 0.79 & Serbia and Montenegro & -0.75 & -0.45 & -0.40 & -0.40 & -0.34 \\
\hline Lebanon & -0.39 & -0.09 & -0.08 & -0.01 & 0.11 & France & -0.82 & -0.45 & -0.45 & -0.43 & -0.39 \\
\hline Tunisia & -0.37 & -0.10 & -0.09 & -0.06 & -0.02 & Bhutan & -0.76 & -0.45 & -0.44 & -0.35 & -0.11 \\
\hline Ghana & -0.22 & -0.12 & -0.12 & -0.09 & -0.07 & Jersey & -0.78 & -0.46 & -0.45 & -0.42 & -0.37 \\
\hline Dem. Peop. Rep. of Korea & -0.74 & -0.12 & -0.07 & 0.06 & 0.20 & Angola & -0.52 & -0.46 & -0.46 & -0.44 & -0.44 \\
\hline Sierra Leone & -0.24 & -0.16 & -0.16 & -0.14 & -0.12 & Guernsey & -0.77 & -0.46 & -0.45 & -0.42 & -0.38 \\
\hline Viet Nam & -0.80 & -0.17 & -0.15 & -0.00 & 0.08 & Romania & -0.78 & -0.46 & -0.43 & -0.43 & -0.35 \\
\hline Belgium & -0.84 & -0.19 & -0.18 & -0.16 & -0.12 & Uganda & -0.65 & -0.46 & -0.46 & -0.43 & -0.39 \\
\hline Nepal & -0.70 & -0.20 & -0.18 & -0.05 & 0.27 & Bosnia-Herzegovina & -0.75 & -0.46 & -0.44 & -0.43 & -0.38 \\
\hline Malta & -0.49 & -0.22 & -0.21 & -0.19 & -0.14 & Andorra & -0.79 & -0.46 & -0.46 & -0.44 & -0.40 \\
\hline Afghanistan & -0.41 & -0.22 & -0.22 & -0.18 & -0.15 & Luxembourg & -0.85 & -0.47 & -0.47 & -0.45 & -0.42 \\
\hline Marocco & -0.43 & -0.22 & -0.22 & -0.18 & -0.12 & Armenia & -0.67 & -0.47 & -0.47 & -0.44 & -0.38 \\
\hline
\end{tabular}

Acknowledgements. We acknowledge the help of K. Pringle in developing and testing the GMXe submodel, S. Metzger for his contribution to the code and A. Tompkins for discussions. The project leading to these results received funding from the European Research Council under the European Union's Seventh Framework Programme (FP7/2007-2013)/ERC grant agreement no. 226144. We acknowledge the usage of data from the CIRCE project (contract number 036961). We thank the DEISA Consortium (www.deisa.eu), co-funded through the EU FP6 project RI-031513 and the FP7 project RI-222919, for support within the DEISA Extreme Computing Initiative. The simulations for this study have been performed in the DEISA grid. The authors wish also to acknowledge the use of the Ferret program for analysis and graphics in this paper. Ferret is a product of NOAA's Pacific Marine Environmental Laboratory (information is available at http://www.ferret.noaa.gov). 
The service charges for this open access publication have been covered by the Max Planck Society.

Edited by: D. Shindell

\section{References}

ACAP, Asia Center for Air Pollution Research (ACAP): EANET Data on the Acid Deposition in the East Asian Region, Tech. rep., Network Center for EANET, 2011.

Anenberg, S. C., Horowitz, L. W., Tong, D. Q., and West, J. J.: An Estimate of the Global Burden of Anthropogenic Ozone and Fine Particulate Matter on Premature Human Mortality Using Atmospheric Modeling, Environ. Health Persp., 118, 1189-1195, doi:10.1289/ehp.0901220, 2010.

Brauer, M., Amann, M., Burnett, R., Cohen, A., Dentener, F., Ezzati, M., Henderson, S., Krzyzanowski, M., Martin, R., Van Dingenen, R., van Donkelaar, A., and Thurston, G.: Exposure assessment for estimation of the global burden of disease attributable to outdoor air pollution, Environ. Sci. Technol., 46, 652-660, doi:10.1021/es2025752, 2012.

Brunekreef, B. and Holgate, S. T.: Air pollution and health, The Lancet, 360, 1233-1242, doi:10.1016/S0140-6736(02)11274-8, 2002

Builtjes, P.: The LOTOS-Long Term Ozone Simulation Project: Summary Report, TNO Institute of Environmental Sciences, 1992.

Center for International Earth Science Information Network (CIESIN), C. U. U. N. F., (FAO), A. P., and de Agricultura Tropical (CIAT), C. I.: Gridded Population of the World, Version 3 (GPWv3): Population Count Grid, Future Estimates, 2005.

Dawson, J., Racherla, P., Lynn, B., Adams, P., and Pandis, S.: Impacts of climate change on regional and urban air quality in the eastern United States: Role of meteorology, J. Geophys. Res., 114, D05308, doi:10.1029/2008JD009849 2009.

Deeter, M. N., Emmons, L. K., Francis, G. L., Edwards, D. P., Gille, J. C., Warner, J. X., Khattatov, B., Ziskin, D., Lamarque, J.-F., Ho, S.-P., Yudin, V., Attié, J.-L., Packman, D., Chen, J., Mao, D., and Drummond, J. R.: Operational carbon monoxide retrieval algorithm and selected results for the MOPITT instrument, J. Geophys. Res, 108, 4399, 10.1029/2002JD003186, 2003.

Deeter, M., Emmons, L., Edwards, D., Gille, J., and Drummond, J.: Vertical resolution and information content of $\mathrm{CO}$ profiles retrieved by MOPITT, Geophys. Res. Lett, 31, L15112, doi:10.1029/2004GL020235, 2004.

Dentener, F., Stevenson, D., Cofala, J., Mechler, R., Amann, M., Bergamaschi, P., Raes, F., and Derwent, R.: The impact of air pollutant and methane emission controls on tropospheric ozone and radiative forcing: CTM calculations for the period 1990 2030, Atmos. Chem. Phys., 5, 1731-1755, doi:10.5194/acp-51731-2005, 2005.

Dentener, F., Stevenson, D., Ellingsen, K., van Noije, T., Schultz, M., Amann, M., Atherton, C., Bell, N., Bergmann, D., Bey, I., Bouwman, L., Butler, T., Cofala, J., Collins, B., Drevet, J., Doherty, R., Eickhout, B., Eskes, H., Fiore, A., Gauss, M., Hauglustaine, D., Horowitz, L., Isaksen, I. S. A., Josse, B., Lawrence, M., Krol, M., Lamarque, J. F., Montanaro, V., Müller, J. F., Peuch, V. H., Pitari, G., Pyle, J., Rast, S., Rodriguez, J., Sanderson, M.,
Savage, N. H., Shindell, D., Strahan, S., Szopa, S., Sudo, K., Van Dingenen, R., Wild, O., and Zeng, G.: The global atmospheric environment for the next generation, Environ. Sci. Technol., 40, 3586-3594, doi:10.1021/es0523845, 2006.

De Meij, A., Pozzer, A., Pringle, K. J., Tost, H., and Lelieveld, J.: EMAC model evaluation and analysis of atmospheric aerosol properties and distribution with a focus on the Mediterranean region, Atmos. Res., 114-115, 38-69, doi:10.1016/j.atmosres.2012.05.014, 2012.

Dockery, D.: Epidemiologic evidence of cardiovascular effects of particulate air pollution, Environ. Health Persp., 109, 483-486, 2001.

Doering, U., van Aardenne, J., Monni, S., Pagliari, V., Orlandini, L., and SanMartin, F.: CIRCE report D8.1.2 - Evaluation emission database 1990-2005, Tech. rep., Project FP6: 6.3, No. 036961, 2009a.

Doering, U., van Aardenne, J., Monni, S., Pagliari, V., Orlandini, L., and SanMartin, F.: CIRCE report D8.1.3 - Update of gridded emission inventories, addition of period 1990-1999 to 20002005 dataset, Tech. rep., Project FP6: 6.3, No. 036961, 2009 b.

Doering, U., Janssens-Maenhout, G., van Aardenne J., and Pagliari, V.: CIRCE report D.3.3.1, Climate Change and Impact Research in the Mediterranean Environment: Scenarios of Future Climate Change, Tech. rep., IES report 62957, 2010.

Drummond, J. and Mand, G.: The Measurements of Pollution in the Troposphere (MOPITT) instrument: Overall performance and calibration requirements, J. Atmos. Ocean. Tech., 13, 314-320, 1996.

Edgerton, E., Lavery, T., Hodges, M., and Bowser, J.: National Dry Deposition Network: Second Annual Progress Report (1988), Epa/600/3-90/020, Environmental Protection Agency, Research Triangle Park, NC, 1990.

Emmons, L. K., Deeter, M. N., Gille, J. C., Edwards, D. P., Attié, J.-L., Warner, J., Ziskin, D., Francis, G., Khattatov, B., Yudin, V., Lamarque, J.-F., Ho, S.-P., Mao, D., Chen, J. S., Drummond, J. Novelli, P., Sachse, G., Coffey, M. T., Hannigan, J. W., Gerbig, C., Kawakami, S., Kondo, Y., Takegawa, N., Schlager, H., Baehr, J., and Ziereis, H.: Validation of Measurements of Pollution in the Troposphere (MOPITT) CO retrievals with aircraft in situ profiles, J. Geophys. Res, 109, D03309, doi:10.1029/2003JD004101, 2004.

Emmons, L. K., Edwards, D. P., Deeter, M. N., Gille, J. C., Campos, T., Nédélec, P., Novelli, P., and Sachse, G.: Measurements of Pollution In The Troposphere (MOPITT) validation through 2006, Atmos. Chem. Phys., 9, 1795-1803, doi:10.5194/acp-91795-2009, 2009.

EPA: National Ambient Air Quality Standards (NAAQS), http: //www.epa.gov/air/criteria.html, 2005.

Etheridge, D. M., Steele, L. P., Langenfelds, R. L., Francey, R. J., Barnola, J.-M., and Morgan, V. I.: Historical $\mathrm{CO}_{2}$ Records from the Law Dome DE08, DE08-2, and DSS Ice Cores, Trends: A Compendium of Data on Global Change, Carbon Dioxide Information Analysis Cente, Oak Ridge National Laboratory, US Department of Energy, Oak Ridge, Tenn., USA, http://cdiac.esd. ornl.gov/trends/co2/lawdome.html, 1998.

Etheridge, D., Steele, L., Francey, R., and Langenfelds, R.: Historical CH4 Records Since About 1000 A.D. From Ice Core Data, Trends: A Compendium of Data on Global Change, Carbon Dioxide Information Analysis Center, Oak Ridge 
National Laboratory, US Department of Energy, Oak Ridge, Tenn., USA, http://cdiac.ornl.gov/trends/atm_meth/lawdome_ meth.html, 2002.

European Commission: Directive 2008/50/EC of the European Parliament and of the Council of 21 May 2008 on ambient air quality and cleaner air for Europe, 2008.

Fenger, J.: Urban air quality, Atmos. Environ., 33, 4877-4900, doi:10.1016/S1352-2310(99)00290-3, 1999.

Friedrich, R. and Reis, S.: Emissions of air pollutants: measurements, calculations and uncertainties, Springer Verlag, 2004.

Garnaut, R., Howes, S., Jotzo, F., and Sheehan, P.: Emissions in the Platinum Age: the implications of rapid development for climatechange mitigation, Oxford Rev. Econ. Pol., 24, 377-401, 2008.

Giorgi, F. and Meleux, F.: Modelling the regional effects of climate change on air quality, CR Geosci., 339, 721-733, 2007.

Gurjar, B., Butler, T., Lawrence, M., and Lelieveld, J.: Evaluation of emissions and air quality in megacities, Atmos. Environ., 42, 1593-1606, 2008.

Haas-Laursen, D. and Hartley, D.: Consistent sampling methods for comparing models to $\mathrm{CO}_{2}$ flask data, J. Geophys. Res., 102, 19059-19071, 1997.

Hogrefe, C., Lynn, B., Civerolo, K., Ku, J., Rosenthal, J., Rosenzweig, C., Goldberg, R., Gaffin, S., Knowlton, K., and Kinney, P.: Simulating changes in regional air pollution over the eastern United States due to changes in global and regional climate and emissions, J. Geophys. Res, 109, D22301, doi:10.1029/2004JD004690, 2004.

Hooghiemstra, P. B., Krol, M. C., Meirink, J. F., Bergamaschi, P., van der Werf, G. R., Novelli, P. C., Aben, I., and Röckmann, T.: Optimizing global $\mathrm{CO}$ emission estimates using a fourdimensional variational data assimilation system and surface network observations, Atmos. Chem. Phys., 11, 4705-4723, doi:10.5194/acp-11-4705-2011, 2011.

Horowitz, L.: Past, present, and future concentrations of tropospheric ozone and aerosols: Methodology, ozone evaluation, and sensitivity to aerosol wet removal, J. Geophys. Res, 111, D22211, doi:10.1029/2005JD006937, 2006.

HTAP: Task Force on Hemispheric transport of air pollution, Part A: Ozone and Particulate Matter, United Nations, www.htap.org, 2010.

Hurrell, J., Hack, J., Shea, D., Caron, J., and Rosinski, J.: A new sea surface temperature and sea ice boundary dataset for the Community Atmosphere Model, J. Climate, 21, 5145-5153, 2008.

IPCC: Climate Change 2001: The Scientific Basis - Contribution of Working Group I to the Third Assessment Report of the Intergovernmental Panel on Climate Change (IPCC), Cambridge University Press, Cambridge, UK, 2001.

Jacob, D. and Winner, D.: Effect of climate change on air quality, Atmos. Environ., 43, 51-63, 2009.

Jacobson, M. and Streets, D.: Influence of future anthropogenic emissions on climate, natural emissions, and air quality, J. Geophys. Res., 114, D08118, doi:10.1029/2008JD011476, 2009.

Jöckel, P., Sander, R., Kerkweg, A., Tost, H., and Lelieveld, J.: Technical Note: The Modular Earth Submodel System (MESSy) - a new approach towards Earth System Modeling, Atmos. Chem. Phys., 5, 433-444, doi:10.5194/acp-5-433-2005, 2005.

Jöckel, P., Tost, H., Pozzer, A., Brühl, C., Buchholz, J., Ganzeveld, L., Hoor, P., Kerkweg, A., Lawrence, M. G., Sander, R., Steil, B., Stiller, G., Tanarhte, M., Taraborrelli, D., van Aardenne, J., and Lelieveld, J.: The atmospheric chemistry general circulation model ECHAM5/MESSy1: consistent simulation of ozone from the surface to the mesosphere, Atmos. Chem. Phys., 6, 50675104, doi:10.5194/acp-6-5067-2006, 2006.

Kerkweg, A., Buchholz, J., Ganzeveld, L., Pozzer, A., Tost, H., and Jöckel, P.: Technical Note: An implementation of the dry removal processes DRY DEPosition and SEDImentation in the Modular Earth Submodel System (MESSy), Atmos. Chem. Phys., 6, 4617-4632, doi:10.5194/acp-6-4617-2006, 2006 a.

Kerkweg, A., Sander, R., Tost, H., and Jöckel, P.: Technical note: Implementation of prescribed (OFFLEM), calculated (ONLEM), and pseudo-emissions (TNUDGE) of chemical species in the Modular Earth Submodel System (MESSy), Atmos. Chem. Phys., 6, 3603-3609, doi:10.5194/acp-6-3603-2006, 2006 b.

Knowlton, K., Rosenthal, J., Hogrefe, C., Lynn, B., Gaffin, S., Goldberg, R., Rosenzweig, C., Civerolo, K., Ku, J., and Kinney, P.: Assessing ozone-related health impacts under a changing climate, Environ. Health Persp., 112, 1557-1563, doi:10.1289/ehp.7163, 2004.

Krol, M., van Leeuwen, P. J., and Lelieveld, J.: Global OH trend inferred from methyl-chloroform measurements, J. Geophys. Res., 103, 10697-10711, 1998.

Krzyzanowski, M. and Cohen, A.: Update of WHO air quality guidelines, Air Quality, Atmosphere \& Health, 1, 7-13, 2008.

Lamarque, J., Kyle, G., Meinshausen, M., Riahi, K., Smith, S., van Vuuren, D., Conley, A., and Vitt, F.: Global and regional evolution of short-lived radiatively-active gases and aerosols in the Representative Concentration Pathways, Climatic Change, 109, 191-212, doi:10.1007/s10584-011-0155-0, 2011.

Lawrence, M. G. and Crutzen, P. J.: Influence of $\mathrm{NO}_{\mathrm{x}}$ emissions from ships on tropospheric photochemistry and climate, Nature, 402, 167-170, 1999.

Lawrence, M. G., Butler, T. M., Steinkamp, J., Gurjar, B. R., and Lelieveld, J.: Regional pollution potentials of megacities and other major population centers, Atmos. Chem. Phys., 7, 39693987, doi:10.5194/acp-7-3969-2007, 2007.

Lelieveld, J. and Dentener, F. J.: What controls tropospheric ozone?, J. Geophys. Res., 105, 3531-3551, 2000.

Lelieveld, J., Peters, W., Dentener, F., and Krol, M.: Stability of tropospheric hydroxyl chemistry, J. Geophys. Res., 107, 4715, doi:10.1029/2002JD002272, 2002.

Lelieveld, J., Hoor, P., Jöckel, P., Pozzer, A., Hadjinicolaou, P., Cammas, J.-P., and Beirle, S.: Severe ozone air pollution in the Persian Gulf region, Atmos. Chem. Phys., 9, 1393-1406, doi:10.5194/acp-9-1393-2009, 2009.

Levy, H.: Normal atmosphere: arge radical and formaldehyde coincentrations predicted, Science, 173, 141-143, 1971.

Liu, C., Beirle, S., Butler, T., Liu, J., Hoor, P., Jöckel, P., Penning de Vries, M., Pozzer, A., Frankenberg, C., Lawrence, M. G., Lelieveld, J., Platt, U., and Wagner, T.: Application of SCIAMACHY and MOPITT CO total column measurements to evaluate model results over biomass burning regions and Eastern China, Atmos. Chem. Phys., 11, 6083-6114, doi:10.5194/acp11-6083-2011, 2011.

Lu, Z., Streets, D. G., Zhang, Q., Wang, S., Carmichael, G. R., Cheng, Y. F., Wei, C., Chin, M., Diehl, T., and Tan, Q.: Sulfur dioxide emissions in China and sulfur trends in East Asia since 2000, Atmos. Chem. Phys., 10, 6311-6331, doi:10.5194/acp-106311-2010, 2010. 
Lu, Z., Zhang, Q., and Streets, D. G.: Sulfur dioxide and primary carbonaceous aerosol emissions in China and India, 1996-2010, Atmos. Chem. Phys., 11, 9839-9864, doi:10.5194/acp-11-98392011, 2011.

Machida, T., Nakazawa, T., Fujii, Y., Aoki, S., and Watanabe, O.: Increase in the atmospheric nitrous oxide concentration during the last 250 years, Geophys. Res. Lett., 22, 2921-2924, doi:10.1029/95GL02822, 1995.

Meinshausen, M., Smith, S. J., Calvin, K., Daniel, J. S., Kainuma, M. L. T., Lamarque, J.-F., Matsumoto, K., Montzka, S. A., Raper, S. A., Riahi, K., Thomson, A., Velders, G., and van Vuuren, D. P: The RCP greenhouse gas concentrations and their extensions from 1765 to 2300, Climatic Change, 109, 213-241, doi:10.1007/s10584-011-0156-z, 2011.

Miyazaki, K., Eskes, H. J., and Sudo, K.: Global $\mathrm{NO}_{\mathrm{x}}$ emission estimates derived from an assimilation of OMI tropospheric $\mathrm{NO}_{2}$ columns, Atmos. Chem. Phys., 12, 2263-2288, doi:10.5194/acp12-2263-2012, 2012.

Mokdad, A., Marks, J., Stroup, D., and Gerberding, J.: Actual causes of death in the United States, 2000, JAMA-J. Am. Med. Assoc., 291, 1238-1245, doi:10.1001/jama.291.10.1238, 2004.

Nakicenovic, N., Alcamo, J., Davis, G., De Vries, B., Fenhann, J., Gaffin, S., Gregory, K., Grubler, A., Jung, T. Y., Kram, T., Lebre La Rovere, E., Michaelis, L., Mori, S., Morita, T., Pepper, W., Pitcher, H., Price, L., Riahi, K., Roehrl, A., Rogner, H. H., Sankovski, A., Schlesinger, M., Priyadarshi Shukla, P., Smith, S., Swart, R., Van Rooijen, S., Victor, N., and Dadi, Z.: Special report on emissions scenarios: a special report of Working Group III of the Intergovernmental Panel on Climate Change, Tech. rep., 2000.

Novelli, P. C., Masarie, K. A., and Lang, P. M.: Distribution and recent changes of carbon monoxide in the lower troposphere, J. Geophys. Res., 103, 19015-19033, 1998.

Orel, A. E. and Seinfeld, J. H.: Nitrate formation in atmospheric aerosols, Environ. Sci. Technol., 11, 1000-1007, doi:10.1021/es60133a009, 1977.

Pfister, G., Hess, P., Emmons, L., Lamarque, J.-F., Edwards, D., Petron, G., Gille, J., and Sachse, G.: Quantifying CO emissions from the 2004 Alaskan wildfires using MOPITT CO data, Geophys. Res. Lett., 32, L11809, doi:10.1029/2005GL022995, 2005.

Plaia, A. and Ruggieri, M.: Air quality indices: a review, Reviews in Environmental Science and Biotechnology, 10, 165179, doi:10.1007/s11157-010-9227-2, 2011.

Pope, C., Burnett, R., Thun, M., Calle, E., Krewski, D., Ito, K., and Thurston, G.: Lung cancer, cardiopulmonary mortality, and longterm exposure to fine particulate air pollution, JAMA-J. Am. Med. Assoc., 287, 1132-1141, doi:10.1001/jama.287.9.1132, 2002.

Pozzer, A., Jöckel, P., Sander, R., Williams, J., Ganzeveld, L., and Lelieveld, J.: Technical Note: The MESSy-submodel AIRSEA calculating the air-sea exchange of chemical species, Atmos. Chem. Phys., 6, 5435-5444, doi:10.5194/acp-6-5435-2006, 2006.

Pozzer, A., Jöckel, P., Tost, H., Sander, R., Ganzeveld, L., Kerkweg, A., and Lelieveld, J.: Simulating organic species with the global atmospheric chemistry general circulation model ECHAM5/MESSy1: a comparison of model results with observations, Atmos. Chem. Phys., 7, 2527-2550, doi:10.5194/acp-72527-2007, 2007.
Pozzer, A., Jöckel, P., and Van Aardenne, J.: The influence of the vertical distribution of emissions on tropospheric chemistry, Atmos. Chem. Phys., 9, 9417-9432, doi:10.5194/acp-9-9417-2009, 2009.

Pozzer, A., de Meij, A., Pringle, K. J., Tost, H., Doering, U. M., van Aardenne, J., and Lelieveld, J.: Distributions and regional budgets of aerosols and their precursors simulated with the EMAC chemistry-climate model, Atmos. Chem. Phys., 12, 961-987, doi:10.5194/acp-12-961-2012, 2012.

Pringle, K. J., Tost, H., Message, S., Steil, B., Giannadaki, D., Nenes, A., Fountoukis, C., Stier, P., Vignati, E., and Lelieveld, J.: Description and evaluation of GMXe: a new aerosol submodel for global simulations (v1), Geosci. Model Dev., 3, 391-412, doi:10.5194/gmd-3-391-2010, 2010a.

Pringle, K. J., Tost, H., Pozzer, A., Pöschl, U., and Lelieveld, J.: Global distribution of the effective aerosol hygroscopicity parameter for CCN activation, Atmos. Chem. Phys., 10, 52415255, doi:10.5194/acp-10-5241-2010, 2010b.

Prinn, R., Cunnold, D., Simmonds, P., Alyea, F., Boldi, R., Crawford, A., Fraser, P., Gutzler, D., Hartley D., Rosen, R., and Rasmussen, R.: Global average concentration and trend for hydroxyl radicals deduced from ALE/GAUGE trichloroethane (methyl chloroform) data for 1978-1990, J. Geophys. Res., 97, 24452461, 1992.

Prinn, R. G., Huang, J., Weiss, R. F., Cunnold, D. M., Fraser, P. J., Simmonds, P. G., McCulloch, A., Harth, C., Salameh, P., O’Doherty, S., Wang, R. J. J., Porter, L., and Miller, B. R.: Evidence for substantial variations of atmospheric hydroxyl radicals in the past two decades, Science, 292, 1882-1888, 2001.

Qian, Y., Gustafson Jr., W. I., and Fast, J. D.: An investigation of the sub-grid variability of trace gases and aerosols for global climate modeling, Atmos. Chem. Phys., 10, 6917-6946, doi:10.5194/acp-10-6917-2010, 2010.

Roeckner, E., Brokopf, R., Esch, M., Giorgetta, M., Hagemann, S., Kornblueh, L., Manzini, E., Schlese, U., and Schulzweida, U.: Sensitivity of simulated climate to horizontal and vertical resolution in the ECHAM5 atmosphere model, J. Climate, 19, 37713791, 2006.

Russ, P., Wiesenthal, T., van Regenmorter, D., and Ciscar, J. C.: Global Climate Policy Scenarios for 2030 and beyond. Analysis of Greenhouse Gas Emission Reduction Pathway Scenarios with the POLES and GEM-E3 models, JRC Reference report EUR $23032 \mathrm{EN}$ http://ipts.jrc.ec.europa.eu/publications/pub.cfm?id= 1510, 2007

Sander, R., Kerkweg, A., Jöckel, P., and Lelieveld, J.: Technical note: The new comprehensive atmospheric chemistry module MECCA, Atmos. Chem. Phys., 5, 445-450, doi:10.5194/acp-5445-2005, 2005.

Schade, B. and Wiesenthal, T.: Comparison of long-term world energy studies. Assumptions and results from four world energy models, report 22398, IPTS EUR report, 2007.

Schöpp, W., Cofala, J., and Klimont, Z.: A review of abatement strategies and national emission ceilings, Report to the RECOVER, 2010.

Shindell, D., Kuylenstierna, J. C. I., Vignati, E., van Dingenen, R., Amann, M., Klimont, Z., Anenberg, S. C., Muller, N., JanssensMaenhout, G., Raes, F., Schwartz, J., Faluvegi, G., Pozzoli, L., Kupiainen, K., Höglund-Isaksson, L., Emberson, L., Streets, D., Ramanathan, V., Hicks, K., Oanh, N. T. K., Milly, G., Williams, 
M., Demkine, V., and Fowler, D.: Simultaneously mitigating near-term climate change and improving human health and food security, Science, 335, 183-189, doi:10.1126/science.1210026, 2012.

Shindell, D., Faluvegi, G., Stevenson, D.S., Krol, M.C., Emmons, L.K., Lamarque, J. -F., Petron, G. Dentener, F.J., Ellingsen, K., Schultz, M.G., Wild, O., Amann, M., Atherton, C.S., Bergmann, D.J., Bey, I., Butler, T., Cofala, J., Collins, W.J., Derwent, R.G., Doherty, R.M., Drevet, J., Eskes, H.J., Fiore, A.M., Gauss, M., Hauglustaine, D.A., Horowitz, L.W., Isaksen, I.S.A., Lawrence, M.G., Montanaro, M., Muller, J.-F., Pitari, G., Prather, M.J., Pyle, J.A., Rast, S., Rodriguez, J.M., Sanderson, M.G., Savage, Nh.H., Strahan, S.E., Sudo, K., Szopa, S., Unger, N., van Noije, T.P.C. and Zeng, G. : Multimodel simulations of carbon monoxide: Comparison with observations and projected near-future changes, J. Geophys. Res., 111, D19, doi:10.1029/2006JD007100, 2006.

Smoydzin, L., Fnais, M., and Lelieveld, J.: Ozone pollution over the Arabian Gulf - role of meteorological conditions, Atmos. Chem. Phys. Discuss., 12, 6331-6361, doi:10.5194/acpd-126331-2012, 2012.

Spivakovsky, C. M., Logan, J. A., Montzka, S. A., Balkanski, Y. J., Foreman-Fowler, M., Jones, D. B. A., Horowitz, L. W., Fusco, A. C., Brenninkmeijer, C. A. M., Prather, M. J., Wofsy, S. C., and McElroy, M. B.: Three-dimensional climatological distribution of tropospheric $\mathrm{OH}$ : Update and evaluation, J. Geophys. Res., 105, 8931-8980, 2000.

Stevenson, D. S., Dentener, F. J., Schultz, M. G., Ellingsen, K., van Noije, T. P. C., Wild, O., Zeng, G., Amann, M., Atherton, C. S., Bell, N., Bergmann, D. J., Bey, I., Butler, T., Cofala, J., Collins, W. J., Derwent, R. G., Doherty, R. M., Drevet, J., Eskes, H. J., Fiore, A. M., Gauss, M., Hauglustaine, D. A., Horowitz, L. W., Isaksen, I. S. A., Krol, M. C., Lamarque, J.-F., Lawrence, M. G., Montanaro, V., Müller, J.-F., Pitari, G., Prather, M. J., Pyle, J. A., Rast, S., Rodriguez, J. M., Sanderson, M. G., Savage, N. H., Shindell, D. T., Strahan, S. E., Sudo, K., and Szopa, S.: Multimodel ensemble simulations of present-day and nearfuture tropospheric ozone, J. Geophys. Res.-Space, 111, D08301, doi:10.1029/2005JD006338, 2006.

Szopa, S., Hauglustaine, D., Vautard, R., and Menut, L.: Future global tropospheric ozone changes and impact on European air quality, Geophys. Res. Lett, 33, L14805, doi:10.1029/2006GL025860, 2006.

Taraborrelli, D., Lawrence, M., Crowley, J., Dillon, T., Gromov, S., Groß, C., Vereecken, L., and Lelieveld, J.: Hydroxyl radical buffered by isoprene oxidation over tropical forests, Nat. Geosci., 5, 190-193, 2012.

Taylor, K., Williamson, D., and Zwiers, F.: The sea surface temperature and sea ice concentration boundary conditions for AMIP II simulations; PCMDI Report, Tech. Rep. 60, Program for Climate Model Diagnosis and Intercomparison, 2000.

Tørseth, K., Aas, W., Breivik, K., Fjæraa, A. M., Fiebig, M., Hjellbrekke, A. G., Lund Myhre, C., Solberg, S., and Yttri, K. E.: Introduction to the European Monitoring and Evaluation Programme (EMEP) and observed atmospheric composition change during 1972-2009, Atmos. Chem. Phys., 12, 5447-5481, doi:10.5194/acp-12-5447-2012, 2012.

Tost, H., Jöckel, P., Kerkweg, A., Pozzer, A., Sander, R., and Lelieveld, J.: Global cloud and precipitation chem- istry and wet deposition: tropospheric model simulations with ECHAM5/MESSy1, Atmos. Chem. Phys., 7, 2733-2757, doi:10.5194/acp-7-2733-2007, 2007a.

Tost, H., Jöckel, P., and Lelieveld, J.: Lightning and convection parameterisations - uncertainties in global modelling, Atmos. Chem. Phys., 7, 4553-4568, doi:10.5194/acp-7-4553-2007, 2007b.

Tsyro, S. G.: To what extent can aerosol water explain the discrepancy between model calculated and gravimetric $\mathrm{PM}_{10}$ and $\mathrm{PM}_{2.5}$ ?, Atmos. Chem. Phys., 5, 515-532, doi:10.5194/acp-5515-2005, 2005.

UNECE: Protocol to the 1979 convention on long-range transboundary air pollution, CLRTAP, to abate acidification, eutrophication and ground level ozone, http://www.epa.gov/air/criteria. html, 1999.

United Nations Department of Economic and Social Affairs/Population Division (UNDP): World Population Prospects: the 2004 Revision, E.05.XIII.12, United Nations, 2005.

van der Werf, G. R., Randerson, J. T., Giglio, L., Collatz, G. J., Mu, M., Kasibhatla, P. S., Morton, D. C., DeFries, R. S., Jin, Y., and van Leeuwen, T. T.: Global fire emissions and the contribution of deforestation, savanna, forest, agricultural, and peat fires (19972009), Atmos. Chem. Phys., 10, 11707-11735, doi:10.5194/acp10-11707-2010, 2010.

van Donkelaar, A., Martin, R. V., Brauer, M., Kahn, R., Levy, R., Verduzco, C., and Villeneuve, P. J.: Global Estimates of Ambient Fine Particulate Matter Concentrations from Satellite-Based Aerosol Optical Depth: Development and Application, Environ. Health Persp., 118, 847-855, doi:10.1289/ehp.0901623, 2010.

van Vuuren, D., den Elzen, M., van Vliet, J., Kram, T., Lucas, P., and Isaac, M.: Comparison of different climate regimes: the impact of broadening participation, Energ. Policy, 37, 5351-5362, 2009.

van Vuuren, D., Edmonds, J., Kainuma, M., Riahi, K., Thomson, A., Hibbard, K., Hurtt, G., Kram, T., Krey, V., Lamarque, J.F., Masui, T., Meinshausen, M., Nakicenovic, N., Smith, S., and Rose, S.: The representative concentration pathways: an overview, Climatic Change, 109, 5-31, doi:10.1007/s10584-0110148-z, 2011a.

van Vuuren, D., Edmonds, J., Kainuma, M., Riahi, K., and Weyant, $\mathrm{J} .:$ A special issue on the RCPs, Climatic Change, 109, 1-4, doi:10.1007/s10584-011-0157-y, 2011b.

Veldt, C.: Updating and upgrading the PHOXA emission data base to 1990, TNO, Apeldoorn, TNO Report, 1992.

Vestreng, V., Myhre, G., Fagerli, H., Reis, S., and Tarrasón, L.: Twenty-five years of continuous sulphur dioxide emission reduction in Europe, Atmos. Chem. Phys., 7, 3663-3681, doi:10.5194/acp-7-3663-2007, 2007.

Vestreng, V., Ntziachristos, L., Semb, A., Reis, S., Isaksen, I. S. A., and Tarrasón, L.: Evolution of $\mathrm{NO}_{\mathrm{x}}$ emissions in Europe with focus on road transport control measures, Atmos. Chem. Phys., 9, 1503-1520, doi:10.5194/acp-9-1503-2009, 2009.

Walker, S. J., Weiss, R., and Salameh, P.: Reconstructed histories of the annual mean atmospheric mole fractions for the halocarbons CFC-11 CFC-12, CFC-113, and carbon tetrachloride, J. Geophys. Res., 105, 14285-14296, doi:10.1029/1999JC900273, 2000.

Wild, O. and Prather, M. J.: Global tropospheric ozone modeling: Quantifying errors due to grid resolution. J. Geophys. Res, 111, D11305, doi:10.1029/2005JD006605, 2006. 
World Health Organization: Air quality guidelines global update 2005, World Health Organization, Bonn, Germany, 2005.

World Health Organization - Regional Office for Europe: Air quality guidelines for Europe, 23, World Health Organization, Copenhagen, 1987.

World Health Organization - Regional Office for Europe: Air quality guidelines for Europe, 2nd Edn., 91, World Health Organization, Copenhagen, 2000.
Zhao, B., Wang, P., Ma, J. Z., Zhu, S., Pozzer, A., and Li, W.: A high-resolution emission inventory of primary pollutants for the Huabei region, China, Atmos. Chem. Phys., 12, 481-501, doi:10.5194/acp-12-481-2012, 2012. 